\title{
DOCTRINA DEL TRIBUNAL CONSTITUCIONAL DURANTE EL TERCER CUATRIMESTRE DE 2016
}

\section{Doctrine of the Constitutional Court during} the Third Four-Month Period of 2016

\author{
JUAN CARLOS DUQUE VILLANUEVA \\ Tribunal Constitucional \\ duque@tribunalconstitucional.es

\section{CARLOS ORTEGA CARBALLO} \\ Tribunal de Cuentas \\ carlos.ortega@tcu.es
}

\section{HERMINIO LOSADA GONZÁLEZ}

Tribunal Constitucional

losada@tribunalconstitucional.es

\section{TOMÁS DE LA QUADRA-SALCEDO JANINI \\ Tribunal Constitucional \\ tquadra@tribunalconstitucional.es}


I. JURISDICCIÓN CONSTITUCIONAL. DERECHO PROCESAL CONSTITUCIONAL. II. FUENTES DEL DERECHO. III. ORGANIZACIÓN TERRITORIAL DEL ESTADO. IV. ORGANIZACIÓN DE LOS PODERES PÚBLICOS. V. DERECHOS FUNDAMENTALES.

\section{JURISDICCIÓN CONSTITUCIONAL. DERECHO PROCESAL CONSTITUCIONAL}

1. La ejecución de sus resoluciones ha sido la temática más destacada de la que se ha ocupado el Tribunal Constitucional (TC) en lo que se refiere a este apartado de la crónica.

Comenzando por dar cuenta de los aspectos más novedosos, los recursos de inconstitucionalidad del Gobierno vasco y de la Generalitat de Cataluña contra la puesta a disposición del TC por la Ley Orgánica 15/2015, de 16 de octubre, de determinados instrumentos o medidas para garantizar la ejecución de sus resoluciones han sido desestimados por las Sentencias (STC) 185/2016 (Pleno), de 3 de noviembre, y 215/2016 (Pleno), de 15 de diciembre, respectivamente ${ }^{1}$. Los recursos presentaban una identidad sustancial, tanto en lo que se refiere a los preceptos impugnados — si bien el promovido por el Gobierno catalán se dirigía contra una medida más que las recurridas por el del Gobierno vasco - como en su fundamentación. No obstante, el Gobierno vasco aducía como primer motivo de inconstitucionalidad la desnaturalización del modelo de jurisdicción constitucional diseñado por el constituyente, ya que las medidas impugnadas supuestamente implicaban un cambio cualitativo en la naturaleza, posición y funciones del TC. Este genérico planteamiento, frente a la mayor concreción del recurso del Gobierno catalán, determinó, como se explica en la STC 215/2016 — en contestación, sin duda, a lo manifestado al respecto por el magistrado Xiol Ríos en su voto particular a la STC 185/2016—, que la resolución del recurso del Gobierno vasco, pese

1 A ambas sentencias formularon un voto particular discrepante la magistrada Asua Batarrita, para quien debió de ser declarada la inconstitucionalidad y nulidad del art. 92.4 b) LOTC — suspensión en sus funciones de autoridades o empleados públicos-, y los magistrados Valdés Dal-Ré y Xiol Ríos, en cuya opinión debió declararse además la inconstitucionalidad y nulidad del art. 92.4 c) LOTC — ejecución sustitutoria-. Sentencias comentadas también infra, pp. 351-353. 
a haberse interpuesto en fecha posterior, precediera a la del recurso del Gobierno de la Generalitat.

En ambas sentencias una doble consideración precede al enjuiciamiento de los preceptos recurridos. La primera, con reproducción de la doctrina de la STC 49/2008 (Pleno), de 9 de abril ${ }^{2}$, referida a la singularidad que el control de constitucionalidad presenta cuando la Ley Orgánica del Tribunal Constitucional (LOTC) constituye su objeto, siendo de observar en este punto un distinto enunciado en una y otra sentencia. En efecto, la STC 185/2016 reproduce en sus términos la STC 49/2008, en concreto, por lo que respecta al alcance y resultado de aquel control, que «debe limitarse a los supuestos en que existe un conflicto evidente e insalvable» (FJ 3) entre la LOTC y el texto constitucional. Sin embargo, la STC 215/2016 omite este inciso - que los autores de los votos particulares a la primera sentencia entendían como expresión de un supuesto "control debilitado» de la LOTC — y precisa que la vinculación de la ley a la Constitución española (CE), también la de la LOTC, es «de carácter negativo, excluyente de toda transgresión constitucional». Para despejar cualquier asomo de duda sobre la posibilidad de un «control debilitado» de la LOTC, el TC afirma, a continuación, que "[e]ste y no otro es - y ha sido- el sentido de nuestra jurisprudencia en relación con el alcance del control de constitucionalidad que cumple llevar a cabo a este Tribunal sobre su Ley Orgánica», de modo que, «en su función de interprete supremo de la Constitución, el Tribunal ha de controlar que el legislador orgánico respeta los límites constitucionales que [...] condicionan su cometido y se imponen a su labor» (FJ 3).

La segunda consideración gira en torno al tipo de control que, en este caso, puede llevarse a cado al verificarse a través de un recurso de inconstitucionalidad. En este sentido se dice en ambas sentencias, no sin reiteración, que el TC ha de ceñirse exclusivamente a contrastar los preceptos impugnados, en los que se incluyen medidas que el legislador ha puesto a su disposición para garantizar con carácter general la efectividad de sus resoluciones, con los mandatos y principios constitucionales supuestamente vulnerados, al margen, por tanto, de su aplicación a supuestos concretos y de su viabilidad en los distintos procesos constitucionales. Estas son cuestiones que procederá abordar, atendiendo a las circunstancias concurrentes, con ocasión de la aplicación a cada caso de aquellas medidas.

a) En la STC 185/2016 se descarta que las medidas de ejecución impugnadas impliquen una desnaturalización del modelo de justicia constitucional.

2 Comentada en REDC, núm. 82, 2008, pp. 211-216 y 224-231. 
La argumentación que sustenta la decisión parte del presupuesto de que al TC, en cuanto que tiene encomendada en exclusiva el ejercicio de la jurisdicción constitucional, le corresponde «la titularidad de una de las potestades en que el ejercicio de la jurisdicción consiste, cual es el de la ejecución de sus resoluciones». Si no fuera así, se afirma, «el Tribunal, único en su orden, carecería de una de las notas esenciales del ejercicio de la función jurisdiccional y con ello de la potestad necesaria para garantizar la supremacía de la Constitución (art. 9.1 CE)» [FJ 9]. Cosa distinta a la titularidad de la potestad de ejecución es la forma o el modo en que se pueda articular esa ejecución y los instrumentos o medidas que a tal fin se establezcan, cuestiones que el constituyente ha dejado a disposición del legislador orgánico. Así pues, concluye la Sentencia, en la reserva de ley orgánica del art. $165 \mathrm{CE}$ «encuentran cobertura, con carácter general, la regulación de la ejecución de las resoluciones del Tribunal Constitucional y, en particular, la medidas previstas para garantizar su cumplimiento y efectividad», con las que se persigue una finalidad que «tiene un fundamento constitucionalmente legítimo, cual es el de garantizar la defensa de la posición institucional del Tribunal Constitucional y la efectividad de sus sentencias y resoluciones, protegiendo su ámbito jurisdiccional frente a cualquier intromisión ulterior de un poder público que pudiera menoscabarla [...], que es lo mismo que decir, preservar la supremacía de la Constitución, a la que todos los poderes públicos están subordinados (art. 9.3 CE), y cuyo supremo intérprete y garante último es este Tribunal en el ejercicio de su función jurisdiccional» (FJ 10).

b) En relación con las concretas medidas cuestionadas, el TC desestima que la facultad de imponer multas coercitivas a autoridades, empleados públicos o particulares responsables del incumplimiento de sus resoluciones [art. 92.4 a) LOTC] constituya una medida sancionadora o punitiva, rechazando, por tanto, la denunciada vulneración del art. $25 \mathrm{CE}$, ya que, como había declarado respecto a este mismo tipo de medida en el ámbito administrativo (STC 239/1988, de 14 de diciembre), obedece "a una función coercitiva, disuasoria o de estímulo respecto a la obligación de todos los ciudadanos y poderes públicos de cumplir las resoluciones del Tribunal Constitucional (arts. 9.1 CE y 87.1 LOTC), tendente a la modificación del comportamiento de quien incumple una resolución del Tribunal Constitucional, estando obligado a su cumplimiento» (STC 215/2016, FJ 8). Así pues, pese a suponer una consecuencia gravosa para quien tiene que soportarla, no se trata, sin embargo, de una medida sancionadora en sentido propio. Tampoco considera que el legislador haya incurrido en un exceso constitucionalmente reprochable al fijar la horquilla del importe de las multas — de tres mil a treinta mil euros«atendida la relevancia del deber jurídico cuyo incumplimiento pretende 
garantizar [...] que ha de revestir, a la vez, entidad suficiente para resultar realmente disuasoria de su incumplimiento" (STC 215/2016, FJ 8). En todo caso, el TC es quien ha de determinar, atendiendo a las circunstancias concurrentes en cada supuesto, el concreto importe de la multa, con respeto siempre al principio de proporcionalidad.

c) En cuanto a la medida de suspensión en sus funciones de las autoridades o empleados públicos responsables del incumplimiento de las resoluciones del TC [art. 92.4 b) LOTC], se descarta también su naturaleza sancionadora y, por consiguiente, la denunciada infracción del principio de legalidad ex art. 25.1 CE. Una vez delimitado su ámbito subjetivo (solo puede imponerse a la autoridad o empleado público responsable del incumplimiento), temporal (por el tiempo preciso para asegurar la observancia del pronunciamiento incumplido) y su alcance (únicamente podrá acordarse si resulta idónea, debiendo necesariamente contraerse al ejercicio de aquellas atribuciones cuya suspensión resulte imprescindible para el cumplimiento de la resolución), el TC entiende que la medida no «responde a una finalidad represiva, retributiva o de castigo, características de las medidas punitivas, sino a la finalidad de garantizar la efectividad y cumplimiento de las resoluciones del Tribunal Constitucional». Se trata, se afirma, «de una medida que el legislador ha concebido, en el ejercicio de su libertad de configuración, directamente vinculada a la ejecución efectiva de las resoluciones del Tribunal Constitucional, en garantía, por consiguiente, de uno de los componentes esenciales de su función jurisdiccional» (STC 215/2016, FJ 10).

d) Igual suerte desestimatoria han merecido los reproches dirigidos a la previsión de la ejecución sustitutoria para garantizar la efectividad de las resoluciones del TC, quien puede requerir, en caso de optar por esta medida, la colaboración del Gobierno de la nación [art. 92.4 c) LOTC]. El título legitimador de la medida no es un supuesto título competencial del Estado, sino «la garantía de la efectividad y cumplimiento de las resoluciones del Tribunal Constitucional», a quien le corresponde el control de la ejecución y del que el Gobierno es mero colaborador. De otra parte, la dicción del precepto, puesto en conexión con el art. 92.2 LOTC, no excluye la posibilidad de que el TC pueda requerir la colaboración de otros poderes o administraciones públicas. Y, en fin, la ejecución sustitutoria — se razona — no tiene que implicar necesariamente que el Estado sustituya a la Comunidad Autónoma en el ejercicio de sus competencias, pues, al margen de que solo puede recurrirse a esta medida cuando resulte constitucionalmente idónea y procedente, su aplicación en todo caso, al igual que la del resto de las medidas impugnadas, «ha de cohonestarse y respetar siempre las previsiones constitucionales y nunca podrán dar lugar a una alteración de la posición institucional del Estado y de 
las comunidades autónomas, conforme a la Constitución y a los Estatutos de Autonomía, y sí solo a la circunstancial adopción de las medidas necesarias y, por tanto, proporcionadas para la ejecución del fallo» (STC 215/2016, FJ 12).

e) Por último, en relación con la potestad conferida al TC de adoptar de oficio o a instancia del Gobierno, sin oír en un primer momento a las partes y cuando concurran circunstancias de especial trascendencia constitucional, las medidas necesarias para asegurar el debido cumplimiento de las resoluciones que acuerden la suspensión de las disposiciones, actos o actuaciones impugnadas (art. 92.5 LOTC), se afirma que no cabe vislumbrar en ella una «ampliación del ámbito y de los efectos de las facultades de suspensión del Tribunal», ni «un fortalecimiento de la prerrogativa conferida al Gobierno por el art. 161.2 $\mathrm{CE}$, que continúa teniendo idéntico carácter y alcance» (STC 215/2106, FJ 14). En definitiva, la medida contemplada en el art. 95.2 LOTC encuentra cobertura, al igual que el resto de las medidas enjuiciadas, en el art. $165 \mathrm{CE}$, siendo su finalidad la de garantizar el debido y efectivo cumplimiento de un concreto tipo de resoluciones del TC.

2. Como consecuencia del denominado "proceso constituyente en Cataluña», durante este cuatrimestre continuó la retahíla de incidentes de ejecución de la STC 259/2015, de 2 de diciembre ${ }^{3}$, que declaró inconstitucional y nula la Resolución de su Parlamento 1/XI, de 9 de noviembre de 2015, «sobre el inicio de proceso político en Cataluña como consecuencia de los resultados electorales de 27 de septiembre de 2015», que inauguró el Auto (ATC) 141/2016, de 19 de julió ${ }^{4}$, que estimó el incidente de ejecución de aquella Sentencia contra la Resolución de la misma Cámara 5/XI, de 20 de enero de 2016, en cuanto disponía la creación de la Comisión de Estudio del Proceso Constituyente.

En el ATC 170/2016 (Pleno), de 6 de octubre, el TC ha estimado un nuevo incidente de ejecución de la citada Sentencia y el referido Auto promovido por el Gobierno de la nación en relación en esta ocasión con la Resolución del Parlamento 263/XI, de 27 de julio de 2016, por la que se ratifica el informe y las conclusiones de la Comisión de Estudio del Proceso Constituyente. En el Auto se reitera la doctrina del ATC 141/2016 sobre la no afectación de la pendencia de los recursos de inconstitucionalidad interpuestos contra la Ley Orgánica 15/2015, de 16 de octubre, para la resolución del incidente de ejecución y el alcance de las facultades que en esta materia corresponden al TC, incluso antes de la aprobación de dicha Ley, así como sobre la

Reseñada en la crónica publicada en REDC, núm. 106, 2016, p. 356.

4 Reseñado en la crónica publicada en REDC, núm. 108, 2016, pp. 231-233. 
vinculación de los poderes públicos, y, en particular, las Asambleas legislativas y sus miembros a las resoluciones del TC.

El TC deja constancia de la mayor entidad que presenta en esta ocasión el incumplimiento de sus resoluciones, ya que en el ATC 141/2016 había advertido a la Mesa de la Cámara y a sus miembros de la inconstitucionalidad de las conclusiones de la referida Comisión y de la obligación de impedir o paralizar cualquier iniciativa que ignorara sus mandatos, a pesar de lo cual fueron sometidas a la consideración y aprobadas por el Pleno. En este sentido, afirma que «nos enfrentamos a la objetiva oposición de un poder público a los pronunciamientos contenidos en la STC 259/2015» (FJ 2) y que "[l]a sucesión temporal de acontecimientos en el ámbito del Parlamento de Cataluña [...] evidencia la pretensión de esa Cámara autonómica de incumplir las resoluciones del Tribunal Constitucional» (FJ 8).

Se declara la inconstitucionalidad y nulidad de la Resolución, ya que, al ratificar y asumir como propias las conclusiones aprobadas por la Comisión de Estudio del Proceso Constituyente, «el Parlamento de Cataluña elude los pronunciamientos de la STC 259/2015 e ignora las advertencias del ATC $141 / 2016$, pues pretende dar continuidad y soporte al denominado "proceso constituyente en Cataluña» dirigido a su desconexión del Estado español al que se refería la Resolución 1/XI, en términos que ya fueron rechazados por inconstitucionales en la STC 259/2015» (FJ 6). Además de la notificación personal del Auto al secretario general y a los miembros de la Mesa de la Cámara, al presidente y a los miembros del Consejo de Gobierno, con la advertencia de que se abstengan de llevar a cabo cualquier actuación contraria a la resolución del TC y del deber de impedir cualquier iniciativa que pretenda ignorarla y eludirla, en esta ocasión el TC acuerda deducir testimonio de particulares para que el Ministerio Fiscal, si lo estima procedente, ejerza las acciones que corresponda ante el Tribunal competente, acerca de la eventual responsabilidad en la que hubieran podido incurrir la presidenta del Parlamento o cualesquiera otras personas por incumplir el art. 87.1 LOTC. Un reproche expreso le merece al TC la actuación de la presidenta de la Cámara, que ha permitido que se votara la alteración del orden del día propuesta por dos grupos parlamentarios, lo que dio lugar a la aprobación de la Resolución 263/XI, pues «constituye un incumplimiento objetivo de su deber de impedir o paralizar cualquier iniciativa que suponga ignorar o eludir los mandatos enunciados en la STC 259/2015 y el ATC 141/2016, deber del que se le advirtió de manera expresa, en su calidad de Presidenta de la Mesa del Parlamento" (FJ 8).

El mismo día que el TC dictó el ATC 170/2016, el Parlamento de Cataluña aprobó la Resolución 306/XI sobre la Orientación Política General del 
Gobierno, algunos de cuyos apartados han dado lugar a un nuevo incidente de ejecución de la STC 259/2015 promovido por el Gobierno de la nación, que ha sido admitido a trámite por providencia de 13 de diciembre de 2016. Prosigue, por tanto, la serie de incidentes de ejecución, si bien, la resolución de este último tendrá lugar, a diferencia de los anteriores, una vez desestimados los recursos de inconstitucionalidad interpuestos contra la Ley Orgánica $15 / 2015$, despejadas, pues, las dudas sobre la viabilidad de las medidas o instrumentos puestos a disposición del TC para velar por la efectividad de sus resoluciones.

3. El TC se ha pronunciado por vez primera en el ATC 168/2016 (Pleno), de 4 de octubre, sobre la precedencia en un mismo proceso del planteamiento de la cuestión de inconstitucionalidad o de la cuestión prejudicial ante el Tribunal de Justicia de la Unión Europea (TJUE) respecto de idénticos preceptos legales. Del requisito procesal de la aplicación al caso de la norma cuestionada ex arts. 163 CE y 35 LOTC infiere que la prioridad en el planteamiento «debe corresponder, por principio, a la cuestión prejudicial», pues «la incompatibilidad de la ley nacional con el Derecho de la Unión Europea sería causa de su inaplicabilidad y, por tanto, faltaría una de las condiciones procesales para la admisibilidad de la cuestión de inconstitucionalidad", que solo podría admitirse «si se ha descartado la posibilidad de que la ley cuestionada sea incompatible con el Derecho de la Unión y, en consecuencia, inaplicable» (FJ 4). Así pues, si el órgano judicial alberga dudas sobre la compatibilidad de una norma legal con la CE y con el derecho de la Unión Europea (UE), habrá de plantear primero la cuestión prejudicial y solo una vez descartada su incompatibilidad con este último podría promover la cuestión de inconstitucionalidad ${ }^{5}$.

La inadmisión por inadecuación del juicio de aplicabilidad al no respetarse el orden de precedencia expuesto es la consecuencia no solo del planteamiento simultáneo en un mismo proceso deunacuestión deinconstitucionalidad y una cuestión prejudicial sobre idénticos preceptos legales, sino también la del planteamiento de la cuestión de inconstitucionalidad cuando el órgano judicial albergue dudas sobre la compatibilidad de la norma legal con el derecho de la UE, aunque no hubiese promovido aún una cuestión prejudicial, ya

Doctrina que se reitera en los AATC 183 y 185/2016 (Pleno), de 15 de noviembre, si bien en ambos casos, tras afirmarse que no se ha realizado adecuadamente el juicio de aplicabilidad, se procede a examinar, a continuación, si la cuestión de inconstitucionalidad resulta notoriamente infundada, con lo que se lleva a cabo, en consecuencia, un examen de fondo sobre la duda de constitucionalidad planteada. 
que la irresuelta decisión acerca de la incompatibilidad entre la norma nacional y el derecho de la UE, de confirmarse, sería causa de su inaplicabilidad en el proceso a quo y, por tanto, faltaría una de las condiciones exigidas para la admisibilidad de la cuestión de inconstitucionalidad (ATC 202/2016 [Pleno], de 13 de diciembre) $)^{6}$.

4. La STC 204/2016 (Pleno), de 1 de diciembre?, inadmite a trámite una cuestión de inconstitucionalidad, al considerar el TC no aplicable al caso el precepto legal cuestionado por el juego de la cláusula de prevalencia del art. 149.3 CE, sobre la base de la doctrina constitucional sentada en la STC


sobrevenida desplaza en los supuestos en los que no se cuestiona su constitucionalidad a la legislación autonómica de desarrollo. La Sentencia amplía el ámbito de los supuestos en que resulta aplicable esta doctrina, pues estima que lo es no solo cuando la legislación autonómica se haya limitado a reproducir un precepto básico posteriormente modificado, sino también cuando el precepto autonómico haya sido dictado en ausencia de legislación básica, dado que "[e]n ambos casos se trata de una ley autonómica a la que, en el momento en el que se dictó, no podía imputarse vicio alguno de inconstitucionalidad, y que, sin embargo, deviene incompatible con una ley básica del Estado aprobada con posterioridad» $(\mathrm{FJ} 3)^{9}$.

6 En el mismo sentido, AATC 203, 204 y 205/2016 (Pleno), de 13 de diciembre.

7 Véase también infra pp. 358-361.

8 Reseñada en REDC, núm. 108, 2106, pp. 237-238; 239-241; 250-252. Doctrina que se aplica también en el ATC 167/2016 (Pleno), de 4 de octubre.

9 A la Sentencia formuló voto particular la magistrada Asua Batarrita, en el que se remite al formulado a la STC 102/2016, con el añadido, por lo que a este caso se refiere, de que no se dan en él las tres circunstancias señaladas en aquella Sentencia determinantes del juego de la cláusula de prevalencia: el carácter de lex repetita de la norma autonómica cuestionada; la falta de competencia autonómica sobre la materia en el momento de dictarse el precepto cuestionado; y, en fin, la previa declaración por este Tribunal del carácter básico de la norma estatal. A las distintas circunstancias de la STC 102/2016 y las de la Sentencia reseñada se refiere también en su voto particular del magistrado Martínez-Vares García, para quien la aplicación al supuesto ahora considerado de la doctrina sentada en dicha Sentencia supone «la apertura de una grieta en el monopolio de este Tribunal en la fiscalización de la constitucionalidad de las leyes postconstitucionales», ocasionando «la aparición de un control difuso de constitucionalidad de la leyes, ejercido por la jurisdicción ordinaria, sin posibilidad de ulterior supervisión de este Tribunal». No formularon voto particular a la Sentencia el magistrado Ollero Tassara, que se adhirió al voto particular formulado 
5. La STC 178/2016 (Pleno), de 20 de octubre, considera como objeto idóneo de un conflicto positivo de competencias la decisión del Gobierno Vasco, de fecha indeterminada, de abonar a los trabajadores del sector público la paga extraordinaria de diciembre de 2012. Una decisión que tuvo materialmente reflejo en las manifestaciones de la portavoz del Gobierno Vasco recogidas en su página web, en las que confirmó dicho abono, y en la firma por la directora de la función pública de la orden para librar a tal efecto la correspondiente partida presupuestaria. El TC entiende, frente al óbice de admisibilidad alegado, que no estamos ante un conflicto preventivo, al haberse formalizado sin que se hubiera materializado jurídicamente aquella decisión, sino ante la denuncia de una vulneración actual y efectiva de las competencias del Estado, pues la decisión del Gobierno Vasco se configura como un acto resolutorio, en el que manifiesta la voluntad de poner en marcha el procedimiento para el abono de la paga extraordinaria, dirigido al aparato administrativo para la realización de las actuaciones precisas en orden a su cumplimiento, que tiene su reflejo en la orden del libramiento de los correspondientes fondos presupuestarios. En definitiva, concluye el TC, las actuaciones impugnadas han de ser entendidas como un acto imputable al Gobierno Vasco que viene a expresar una afirmación de competencia que el Estado considera que desborda su ámbito propio.

Por su parte, la STC 216/2016 (Pleno), de 15 de diciembre, inadmite a trámite el conflicto positivo de competencias promovido por el Consejo de Gobierno de Castilla La Mancha contra el Real Decreto 1/2016, de 8 de enero, ya que incluye en la demarcación hidrográfica del Júcar determinadas cuencas intracomunitarias valencianas. Una inadmisión fundada en la falta de una auténtica vindicatio potestatis, pues la comunidad autónoma actora no denuncia una invasión de su competencia en materia de cuencas intracomunitarias, sino la de la Comunidad Valenciana, y en la carencia de un efectivo menoscabo de sus competencias, dado que no cabe apreciar la imprescindible conexión que necesariamente ha de existir entre el objeto del conflicto y el propio ámbito competencial, resultando insuficiente al respecto la genérica invocación de títulos competenciales diversos sin más relación con aquel objeto que la hipotética utilización del agua como recurso.

6. Por lo que se refiere al proceso de amparo, la STC 154/2016 (Pleno), de 22 de septiembre, deniega legitimación a una asociación para recurrir, en

por la magistrada Asua Batarrita a las SSTC 116 y 127/2016; ni los magistrados Valdés Dal-Ré y Narváez Rodríguez, que se adhirieron al voto particular formulado por la vicepresidenta a esta última Sentencia. 
defensa de los derechos de terceras personas a la libertad personal (art. 17.2, 3 y $4 \mathrm{CE}$ ) y a la tutela judicial efectiva (art. 24.1 CE), las resoluciones judiciales que desestimaron la incoación de oficio del procedimiento de habeas corpus instado por la asociación demandante en relación con la permanencia de inmigrantes bajo la custodia de la Guardia Civil sin haber sido puestos a disposición judicial.

El TC, con base en una reiterada doctrina constitucional sobre la legitimación activa en el recurso de amparo, conforme a la cual, además de ser parte en el proceso previo, es preciso invocar un interés legítimo, resultando imprescindible la vinculación de ese interés con el derecho fundamental vulnerado, pone de manifiesto que las asociaciones no figuran entre los sujetos legalmente legitimados para instar el proceso de habeas corpus (art. 3 LOHC), razón por la que la recurrente se limitó a pedir al Juzgado que hiciera uso de su potestad de incoarlo de oficio, quedando agotadas sus posibilidades procesales en esa petición, de modo que no cabe «reconocerle su condición de parte en el proceso judicial de origen, circunstancia que por sí misma [...] sería suficiente para negarle legitimación activa en el recurso de amparo [art. 46.1.b) LOTC]». El TC añade que tampoco puede reconocérsele un interés legítimo, pues este no puede residenciarse en «la contribución "al efectivo ejercicio del derecho a la tutela judicial efectiva de las personas extranjeras"», ya que tal interés no puede confundirse con un «interés genérico en la preservación de derechos». Es evidente — concluye la Sentencia - que «ni la recurrente es la titular del derecho de habeas corpus, ni del resto de los derechos fundamentales supuestamente vulnerados [...] ni puede, dada la naturaleza eminentemente personal del derecho tutelado, ampliarse en sede de amparo el restringido circulo de legitimados que reconoce el art. $3 \mathrm{LOHC»}(\mathrm{FJ} 3)^{10}$.

7. El TC puede abordar el cumplimiento del requisito de la justificación de la especial trascendencia constitucional del recurso de amparo (art. 49.1 in fine LOTC), al igual que ocurre con el resto de sus presupuestos de admisibilidad, en fase de sentencia, una vez, por tanto, admitido a trámite y apreciada en este momento procesal su especial trascendencia constitucional (art. 50.1 LOTC). Con base en esta doctrina, la STC 146/2016 (Sala Primera), de 19 de septiembre, inadmitió un recurso de amparo al no considerar justificación bastante la ofrecida por el demandante, sin que pueda

10 A la Sentencia formularon voto particular discrepante los magistrados Asua Batarrita, Valdés Dal-Ré y Xiol Ríos, al que se adhirió el magistrado Narváez Rodríguez, para quienes la asociación recurrente no carecía de legitimación, debiendo haberse otorgado el amparo solicitado por vulneración del derecho a la libertad. 
entenderse satisfecho dicho requisito con la mera cita o transcripción de los motivos recogidos en la STC 155/2009, de 25 de junio, FJ 2, huérfanas de toda argumentación ${ }^{11}$.

8. El motivo de especial trascendencia constitucional más cuantitativamente apreciado en los recursos resueltos durante este cuatrimestre ha sido el referido a darle al TC ocasión para aclarar o cambiar su doctrina como consecuencia de un proceso de reflexión interna o de cambios normativos relevantes [STC 155/2009, de 25 de junio, FJ 2 b)]. Motivo cuyo contorno en la práctica trasciende su enunciado literal, pues tiene cabida en él como revela la lectura de las sentencias, no una aclaración o cambio propiamente dicho de una precedente doctrina constitucional sobre el concreto derecho fundamental concernido, sino más bien la aplicación de esta doctrina, que ni se aclara, perfila o cambia, a un supuesto de hecho, algunas veces inédito, pero las más de las ocasiones que solo presenta alguno o algunos elementos fácticos novedosos dudosamente significativos para la referida doctrina constitucional. Es suficiente con traer a colación, a título de ejemplo, entre otras, las SSTC 148/2016 (Sala Segunda), de 19 de septiembre; 149/2016 (Sala Segunda), de 19 de septiembre; 161/2016 (Sala Segunda), de 3 de octubre; 162/2016 (Sala Primera), de 3 de octubre; 163/2016 (Sala Segunda), de 3 de octubre; 166/2016 (Pleno), de 6 de octubre; 176/2016 (Sala Primera), de 17 de octubre); 222/2016 (Sala Segunda), de 19 de diciembre.

En fin, como pone de manifiesto la seria de sentencias dictadas frente a resoluciones judiciales que archivaron procesos individuales de validez de cláusulas suelo por litispendencia de un proceso colectivo (que inicia la STC 148/2016 [Sala Segunda], de 19 de septiembre, y culmina en este cuatrimestre la STC 223/2016 [Sala Segunda], de 19 de diciembre), la especial trascendencia constitucional cabe apreciarla de cada uno de los recursos de amparo, todos ellos interpuestos y admitidos a trámite antes de que se dictara la primera de las sentencias, sin que fuera obstáculo para ello que las demandas suscitasen idéntica problemática constitucional, tanto desde la perspectiva del derecho fundamental invocado como de la ratio decidendi de las resoluciones judiciales impugnadas, coincidiendo sustancialmente, por lo tanto, su objeto ${ }^{12}$.

11 A la Sentencia formuló voto particular discrepante el magistrado Xiol Ríos, para quien el TC únicamente puede revisar en Sentencia el juicio inicial sobre la justificación de la especial trascendencia constitucional cuando concurran circunstancias excepcionales, sin que la Sentencia aluda a ninguna circunstancia de esta clase.

12 Juan Carlos Duque Villanueva. 


\section{FUENTES DEL DERECHO}

1. Durante este cuatrimestre son seis las sentencias que se han ocupado del problema de la concurrencia del presupuesto habilitante para la utilización del Decreto-ley, lo que reitera la consolidada doctrina del TC al respecto.

a) La STC 169/2016 (Pleno), de 6 de octubre, estima el recurso de inconstitucionalidad interpuesto contra el art. 1.1 del Real Decreto-ley 7/2015, de 14 de mayo, por el que se conceden créditos extraordinarios y un suplemento de crédito en el presupuesto del Ministerio de Defensa para atender al pago de obligaciones correspondientes a programas especiales de armamento, por no resultar justificado el presupuesto habilitante del art. 86.1 CE. El TC reitera los razonamientos de la STC 126/2016 (Pleno), de 7 de julio ${ }^{13}$, que resolvió el recurso de inconstitucionalidad interpuesto contra el art. 2.1 del Real Decreto-ley 10/2014, una disposición recurrida porque planteaba el mismo problema constitucional. Con cita de la STC 126/2016, la STC 169/2016 critica de nuevo el recurso sistemático al Decreto-ley «como forma jurídica de vehicular créditos extraordinarios para financiar los programas especiales de armamento» (FJ 3). La limitación de efectos de la declaración de nulidad del Decreto-ley enjuiciado (FJ 4), como en el caso de la STC 126/2016, atenúa el impacto del pronunciamiento del TC, pero, seguramente, no sería correcto desdeñar el alcance del reproche a esa práctica gubernativa de acudir sistemáticamente al Decreto-ley para financiar los programas especiales de armamento, en lo que tiene de advertencia sobre el mal uso de esta fuente del derecho.

b) La STC 183/2016 (Pleno), de 3 de noviembre, considera, partiendo de la doctrina sentada en la STC 139/2016 (Pleno), de 21 de julio ${ }^{14}$, que el precepto del Real Decreto-ley 16/2012, de 20 de abril, de medidas urgentes para garantizar la sostenibilidad del Sistema Nacional de Salud y mejorar la calidad y seguridad de sus prestaciones, que dispone la integración de médicos, practicantes y matronas titulares de los servicios sanitarios locales en los servicios de salud de las comunidades autónomas como personal estatutario fijo, no infringe el art. 86.1 CE. Entiende la STC 183/2016 cumplido el presupuesto habilitante tanto en lo que atañe a la justificación por el Gobierno de la existencia de una situación de extraordinaria y urgente necesidad (una grave situación económica del Sistema Nacional de Salud) como en lo que se refiere a la conexión de sentido entre la situación de urgencia apreciada y la concreta

13 Reseñada en REDC, núm. 108, 2016, p. 244.

14 Reseñada en REDC, núm. 108, 2016, pp. 244-245. 
medida cuestionada (integración de funcionarios de los servicios sanitarios locales en los servicios de salud autonómicos):

[...] por cuanto con ella se busca reducir la diversidad de regulaciones del personal del Sistema Nacional de Salud, buscando una racionalización de los recursos humanos disponibles [...] Se trata de una medida que forma parte de un conjunto sistemático de reformas relacionadas con los recursos humanos del Sistema Nacional de Salud, las cuales, en su finalidad de adecuación del gasto de personal, adquieren sentido en su visión global y no desde una perspectiva meramente aislada (FJ 3).

c) La STC 195/2016 (Pleno), de 16 de noviembre, descarta la vulneración del art. 86.1 CE que se alegaba en el recurso de inconstitucionalidad interpuesto contra sendos preceptos del Real Decreto-ley 8/2014, de 4 de julio, de aprobación de medidas urgentes para el crecimiento, la competitividad y la eficiencia, relativos a la declaración de zonas de gran afluencia turística y la liberalización de horarios comerciales. Siguiendo la doctrina sentada en la STC 199/2015 (Pleno), de 24 de septiembre ${ }^{15}$ (FJ 6), para un asunto similar, la STC 195/2016 considera que también en este caso concurren la justificación del presupuesto habilitante y la conexión de sentido entre la situación de urgencia definida por el Gobierno y la medida normativa discutida (FJ 3) ${ }^{16}$.

d) La STC 157/2016 (Pleno), de 22 de diciembre, reitera la doctrina sobre el presupuesto habilitante en relación con los Decretos-leyes autonómicos (FFJJ 4 y 5). Descarta (FJ 6) que el Decreto-ley de la Generalitat de Cataluña 7/2014, de 23 diciembre, que deroga determinados preceptos del Decreto-ley 1/2009, de 22 de diciembre, de Ordenación de los Equipamientos Comerciales (lo que en la práctica supone la derogación de dos supuestos, en los que excepcionalmente, esta norma permite la implantación de determinados centros comerciales fuera de la trama urbana consolidada de determinados municipios) haya sido dictado sin que exista una situación de necesidad extraordinaria y urgente, como exige el art. 64.1 del Estatuto Autonómico de

15 Reseñada en REDC, núm. 106, 2016, pp. 347-348.

16 A la Sentencia formularon un voto particular discrepante los magistrados Asua Batarrita y Valdés Dal Ré, quienes consideran, por las mismas razones que ya expusieran en su voto particular a la STC 199/2015, que también en este caso la Sentencia debiera haber sido estimatoria del recurso, al haberse producido una extralimitación del presupuesto habilitante de la extraordinaria y urgente necesidad que para aprobar decretos-leyes exige el art. 86.1 CE. 
Cataluña (EAC) para que el Gobierno de la Generalitat pueda dictar este tipo de normas.

e) Del mismo modo, la STC 211/2016 (Pleno), de 15 de diciembre, reitera la doctrina sobre el presupuesto habilitante en los Decretos-leyes autonómicos (FJ 3), para concluir en el caso enjuiciado (FFJ 4 y 5) que en el Decreto-ley de la Generalitat de Cataluña 4/2012, de 30 de octubre, de medidas en materia de horarios comerciales y determinadas actividades de promoción (apertura en domingos y festivos y temporada de rebajas), concurre el presupuesto habilitante de la extraordinaria y urgente necesidad.

2. La STC 170/2016 (Pleno), de 6 de octubre, desestima el recurso de inconstitucionalidad interpuesto contra un precepto de la Ley 4/2015, de 18 de diciembre, de Modificación de la Ley 9/2001, del Suelo de la Comunidad de Madrid, que establece un límite de altura a los edificios de nueva construcción («ley de las tres alturas»).

Los diputados recurrentes consideran que el precepto impugnado vulnera el art. 9.3 CE al tratarse de una ley singular que participa al mismo tiempo de los caracteres de una norma legal autoaplicativa y de una ley de supuesto de hecho concreto, que no aparece motivada suficientemente, no está justificada e incluye una solución desproporcionada. Además, consideran vulnerado el art. 117.3 CE en relación con el art. 9.3 CE, por tratarse de una norma meramente interpretativa que tiene por finalidad imponer al poder judicial, con efecto retroactivo, una única interpretación de una ley anterior. Y en tercer y último lugar, alegan la vulneración del derecho a la tutela judicial efectiva (art. 24.1 CE), al impedir la norma el acceso a la justicia de los titulares de derechos e intereses legítimos, incumplir el requisito de equivalencia material del control judicial y privar de efectividad a las resoluciones judiciales recaídas en conexión con la materia objeto de la norma cuestionada.

La STC 170/2016, tras constatar que la norma recurrida "pretende la inaplicación de la limitación de alturas a determinadas situaciones jurídicas pendientes para facilitar la implantación del nuevo modelo urbanístico» (FJ 3), advierte que el primer y tercer motivo del recurso han de examinarse conjuntamente, pues ambos motivos de inconstitucionalidad parten de la premisa de la naturaleza singular de la norma impugnada, al considerar que participa simultáneamente de los caracteres de ley autoaplicativa y de ley de supuesto de hecho concreto. Trae seguidamente a colación la STC 170/2016 la doctrina del TC en materia de leyes singulares (FJ 4), para concluir (FJ 5) que la norma impugnada no es un supuesto de ley autoaplicativa, pues se trata de una norma transitoria «impropia», que persigue solucionar la colisión temporal de las leyes y facilitar la implantación del nuevo modelo urbanístico que 
inspira a la Ley 4/2015 y su derogación de la limitación de alturas. También descarta la STC 170/2016 que se trate de una ley de destinatario único o de estructura singular en atención a los destinatarios a los que va dirigida, pues tiene por objeto regular situaciones jurídicas iniciadas con anterioridad para favorecer la implantación del nuevo modelo urbanístico. Rechaza, en fin, que se trate de una ley singular dictada en atención a un supuesto de hecho concreto, pues es una norma con vocación de generalidad, que tiene como pretensión someter al conjunto de los planes urbanísticos en el ámbito territorial de la Comunidad de Madrid a la misma regla de derecho que con carácter general se establece tras la entrada en vigor de la Ley 4/2015, Derogatoria de la Limitación de Alturas.

Niega por último la STC 170/2016 que el precepto impugnado sea una norma meramente interpretativa cuyo objeto sea imponer al poder judicial (y, además, con efecto retroactivo), una única interpretación sobre un precepto ya en vigor. La norma recurrida hace lo que le es propio, esto es, innovar el ordenamiento jurídico: por una parte, derogando una norma anterior $y$, por otra, estableciendo una nueva regulación transitoria, para favorecer la implantación del nuevo modelo urbanístico adoptado (FJ 6).

3. En la STC 203/2016 (Pleno), de 1 de diciembre ${ }^{17}$, el TC ha tenido ocasión de resolver por vez primera una cuestión prejudicial de validez de una norma foral fiscal de los Territorios Históricos Vascos, nuevo proceso constitucional regulado por la disposición adicional 5. ${ }^{a}$ LOTC, añadida por la Ley Orgánica 1/2010, de 19 de febrero, después de que la STC 118/2016, de 23 de junio $^{18}$, declarase la conformidad con la CE de esa reforma legal.

La STC 203/2016 extiende a las cuestiones prejudiciales de validez la doctrina constitucional sobre la pervivencia de objeto de las cuestiones de inconstitucionalidad cuando el precepto cuestionado, tras su derogación o modificación, sigue resultando aplicable en el proceso a quo y de su validez depende la decisión a adoptar en él (la norma foral fiscal cuestionada había sido ya derogada por otra que seguía un criterio distinto). En cuanto al fondo, el TC estima la cuestión prejudicial y declara inconstitucional y nula la norma foral fiscal porque introduce modificaciones en el método de estimación objetiva de determinación de la base imponible del IRPF que no obedecen a peculiaridad alguna contenida en la Ley del concierto económico, que es parámetro inmediato de la validez de las normas forales fiscales, conforme declaró la STC 118/2016, FJ 3.c).

17 Comentada también infra, pp. 357-358.

18 Reseñada en REDC, núm. 108, 2016, pp. 235-237 y 241-242. 
4. El principio de seguridad jurídica (art. 9.3 CE), en su vertiente de protección de la confianza legítima, ha operado como canon de control en la STC 181/2016 (Pleno), de 20 de octubre, en relación con determinados preceptos del Real Decreto-ley 9/2013, de 12 de julio, por el que se adoptan medidas urgentes para garantizar la estabilidad financiera del sistema eléctrico, y que establecen un nuevo régimen retributivo para los titulares de las instalaciones de producción de energía eléctrica en régimen primado. La STC 181/2016, tras analizar la evolución normativa del régimen retributivo de las empresas distribuidoras del sector eléctrico y traer a colación la doctrina sentada en la STC 270/2015 (Pleno), de 17 de diciembre ${ }^{19}$, concluye que no existe quiebra alguna del principio de confianza legítima, pues la propia provisionalidad de la regulación precedente en la que se basa la pretensión de las empresas excluye que esa normativa pudiera generar cualquier tipo de expectativa encuadrable en el principio de confianza legítima constitucionalmente garantizado.

5. El principio de interdicción de la arbitrariedad de los poderes públicos (art. 9.3 CE), también ha operado como canon de control en varias sentencias.

Así, en la STC 167/2016 (Pleno), de 6 de octubre, el TC descarta la duda de constitucionalidad que plantea la Sala de lo Contencioso-Administrativo de la Audiencia Nacional en relación con una disposición del Real Decreto-ley 14/2010, de 23 de diciembre, por el que se establecen medidas urgentes para la corrección del déficit tarifario del sector eléctrico, precepto que impone a determinadas empresas de generación eléctrica la obligación de financiación de planes de ahorro y eficiencia energética, en los distintos porcentajes que establece, a fin de sufragar el déficit tarifario.

Tras declarar la STC 167/2016 que la norma cuestionada no lesiona el principio de igualdad (art. $14 \mathrm{CE}$ ), porque los términos de comparación invocados no son homogéneos y porque, dentro del grupo comparable (las once empresas que cita la norma), la distribución de la carga es proporcionada y se asienta en criterios objetivos, legítimos y razonables, concluye (FJ 7) que también ha de descartarse la vulneración del principio de interdicción de la arbitrariedad de los poderes públicos, habida cuenta de que en un caso como este la supuesta vulneración de este principio constitucional no puede separarse de la del principio de igualdad, puesto que la pretendida arbitrariedad sería el resultado de la falta de una justificación razonable, objetiva y proporcional al

19 Reseñada en REDC, núm. 106, 2016, pp. 351-352. 
fin perseguido por la disposición cuestionada, tacha que la STC 167/2016 ha descartado ${ }^{20}$.

6. Sobre la eventual vulneración del derecho de participación política de los parlamentarios (art. 23.2 CE) como consecuencia de alteraciones o vicios en el procedimiento legislativo se ha pronunciado el TC en varias sentencias dictadas en el cuatrimestre que es objeto de la presente crónica, sin que se aprecien desviaciones de la consolidada jurisprudencia al respecto.

a) La STC 143/2016, de 19 de septiembre ${ }^{21}$ (Sala Primera), aborda un supuesto de reducción excepcional de plazos (superior a la mitad de los que corresponderían en caso de declaración de urgencia) en la tramitación de leyes presupuestarias. Partiendo de la conocida doctrina sobre el alcance del control del TC sobre la actividad parlamentaria, la STC 143/2016 descarta que se haya infringido el derecho de participación política de los parlamentarios asturianos (art. 23.2 CE) por la decisión de la Mesa de la Junta General del Principado de Asturias de acortar los plazos de tramitación del proyecto de Ley de Presupuestos del Principado para 2013. Esa decisión se fundamenta en una interpretación del Reglamento de la Cámara por parte de la Mesa, con fundamento en la apreciación de una situación habilitante de excepcionalidad, que el TC, desde la limitada perspectiva de control que le corresponde en relación con el enjuiciamiento de los actos parlamentarios, no puede rechazar. Por otra parte, el acortamiento de plazos lo fue para todos los grupos parlamentarios, sin omitir ningún trámite y sin que resulte acreditado que esa reducción afectase esencialmente al proceso de formación de voluntad de los parlamentarios.

b) Mayor interés reviste la STC 153/2016 (Pleno), de 22 de septiembre, que resuelve el recurso de inconstitucionalidad interpuesto contra la Ley de las Cortes Valencianas de Supresión de los Servicios de Radiodifusión y Televisión Autonómicos (Ley 4/2013, de 27 de noviembre). La derogación de esa Ley (y el restablecimiento de los servicios de radiotelevisión autonómicos) comporta la pérdida de objeto del recurso, excepto en lo que atañe a los vicios en el procedimiento legislativo que se denuncian, que el TC descarta. En primer lugar, rechaza que se haya vulnerado el procedimiento legislativo por tener la Ley impugnada su origen en una proposición de ley y no en un proyecto de ley, pues ningún obstáculo se establece en el Estatuto de Autonomía

20 Doctrina que se reitera en las SSTC 174/2016 (Sala Segunda), de 17 de octubre; 187 y 188/2016 (Sala Segunda), de 14 de noviembre; 196/2016 (Sala Segunda), de 28 de noviembre; y 197/2016 (Sala Primera), de 28 de noviembre.

21 Véase infra pp. 366-367. 
o en el Reglamento de la Cámara a la potestad de los grupos parlamentarios de presentar proposiciones de ley. Asimismo, rechaza la alegada lesión del procedimiento legislativo por la falta de presentación de los antecedentes necesarios para pronunciarse sobre la proposición de ley que dio origen a la Ley recurrida, pues es a la propia Mesa a la que corresponde interpretar, de conformidad con la normativa aplicable, qué materiales son imprescindibles en cada caso para realizar adecuadamente el control formal que se plasma en la calificación y en la decisión sobre la admisibilidad de las iniciativas legislativas y para que el debate legislativo se realice con plena libertad de decisión, siendo así que en este caso la Mesa consideró, motivadamente y de manera razonable, que la exposición de motivos contenida en la proposición de ley presentada contenía los antecedentes necesarios para pronunciarse, no siendo una exigencia del Reglamento de la Cámara que la exposición de motivos y los antecedentes se presenten por separado, como se demuestra en la tradición parlamentaria de las Cortes Valencianas. Igualmente rechaza que la tramitación de la proposición de ley por el procedimiento de lectura única haya vulnerado los derechos inherentes a la función parlamentaria de los diputados. En fin, una vez descartada la existencia de vicios en el procedimiento legislativo, el TC desestima en consecuencia la vulneración del principio de seguridad jurídica (art. 9.3 CE), que se vincula en el recurso a la existencia de esos supuestos vicios formales.

c) La STC 213/2016 (Pleno), 15 de diciembre, que resuelve el recurso de inconstitucionalidad promovido por más de cincuenta diputados del Grupo Parlamentario Socialista del Congreso de los Diputados contra la Ley 1/2013, de 14 de mayo, de Medidas para Reforzar la Protección a los Deudores Hipotecarios, Reestructuración de Deuda y Alquiler Social, descarta que la tramitación parlamentaria de una proposición de ley de iniciativa legislativa popular (presentada por dicho grupo parlamentario), conjuntamente con un proyecto de ley, que dio lugar finalmente a la ley recurrida, haya vulnerado la autonomía parlamentaria o el derecho de participación política de los diputados recurrentes. El hecho de que el grupo parlamentario mayoritario hubiera presentado enmiendas a todo el articulado de la proposición de ley (un hecho que no prohíbe el Reglamento del Congreso de los Diputados [RCD]), y que se aprobasen, no comporta vulneración constitucional alguna, sino que deriva del derecho de enmienda y del principio mayoritario, afirma el TC. Tampoco impide el RCD la tramitación conjunta de dos iniciativas legislativas, lo que además es conforme con el uso parlamentario, siempre que exista conexión material entre ambas iniciativas, requisito que en este caso se cumple.

d) La relevante STC 185/2016 (Pleno), de 3 de noviembre, que desestima el recurso de inconstitucionalidad interpuesto por el Gobierno vasco en 
relación con la Ley Orgánica 15/2015, de 16 de octubre, de Reforma de la Ley Orgánica 2/1979, de 3 de octubre, del Tribunal Constitucional, para la Ejecución de las Resoluciones del Tribunal Constitucional como Garantía del Estado de Derecho, descarta el motivo de inconstitucionalidad alegado en relación con el procedimiento legislativo, que afecta a la totalidad de la ley impugnada $^{22}$. Aducía el recurrente la ausencia de los requisitos exigidos por el art. 150 RCD para la tramitación de la proposición de ley por el procedimiento en lectura única (cuando "su naturaleza [...] lo aconsej[e] o la simplicidad de formulación lo permita»), por lo que entendía vulnerado el art. 23.2 CE. El TC rechaza esta tacha porque los diputados no han visto limitadas ni restringidas sus posibilidades de participación en el procedimiento legislativo, cuyo desarrollo se atuvo a las previsiones reglamentarias. La especial relevancia constitucional de un texto normativo, a la luz del referido precepto reglamentario, no es incompatible con su tramitación por el procedimiento en lectura única, ni suficiente por sí misma para excluir la utilización de este procedimiento parlamentario, al que no le está vedada materia alguna, incluida la reforma constitucional; por otra parte, tampoco resulta arbitraria la consideración de la Mesa del Congreso de que la simplicidad de la formulación de la proposición de ley (que no puede confundirse con su relevancia material o trascendencia constitucional), justifica su tramitación por el procedimiento en lectura única, pues la proposición de ley consta de un único artículo, con cuatro apartados, y una disposición final que modifican o dan nueva redacción parcial a cuatro artículos de la LOTC, con una estructura y un lenguaje, desde la perspectiva de cualquier observador razonable, comprensibles, sencillos e inteligibles; en fin, la falta de consenso entre los grupos parlamentarios en orden a la tramitación de la proposición de ley por el procedimiento en lectura única tampoco afecta a la constitucionalidad de esta tramitación, pues la decisión ha sido adoptada por el órgano competente, a propuesta de los órganos facultados para ello, y por la mayoría reglamentariamente establecida (FJ 5$)^{23}$.

\section{ORGANIZACIÓN TERRITORIAL DEL ESTADO}

1. Las SSTC 185/2016 (Pleno), de 3 de noviembre, y 215/2016 (Pleno), de 15 de diciembre ${ }^{24}$, han resuelto las impugnaciones planteadas por el Gobierno

22 Doctrina que se reitera en la STC 215/2016 (Pleno), de 15 de diciembre. Ambas sentencias comentadas también supra, pp. 332-336 e infra pp. 351-352.

23 Herminio Losada González.

24 Véase supra pp. 332-336 y 350-352. 
Vasco y la Generalitat de Cataluña frente a la reforma de la LOTC llevada a cabo por la Ley Orgánica 15/2015, de 16 de octubre, y que incluyó nuevas medidas a disposición del TC para garantizar la ejecución de sus resoluciones.

En aquellos aspectos estrictamente vinculados con la organización territorial, es de destacar que las referidas sentencias distinguen, de una parte, el reproche que de manera conjunta se dirige a las medidas del art. 92.4 b) y c) y 92.5 LOTC por posible alteración del sistema de controles del Estado sobre las comunidades autónomas previsto en la $\mathrm{CE}$, en particular, del mecanismo del art. $155 \mathrm{CE}$; y, de otra, la queja que se formula en relación con el art. 92.4 c) LOTC, por lo que pueda implicar la sustitución de la comunidad autónoma por el Estado en el ejercicio de sus competencias.

En relación con las medidas contempladas en el art. 92.4 b) y c) y 92.5 LOTC, destaca el TC que son medidas que también pueden llegar a adoptarse en relación con el Estado y en modo alguno constituyen mecanismos de control del Estado sobre las comunidades autónomas, estando exclusivamente orientadas a garantizar la efectividad y el cumplimiento de las resoluciones del TC. Para el TC, el art. 155 CE regula una vía específica de coerción directa para el cumplimiento de obligaciones constitucionales y legales y para la protección del interés general de España, que se diferencia nítidamente de la regulación de las medidas de ejecución de que pueda disponer el TC en orden a la efectividad de sus resoluciones, y que encuentra cobertura en la reserva de ley orgánica del art. $165 \mathrm{CE}$. Para el TC las medidas previstas en el art. 92.4 b) y c) y 92.5 LOTC, y el mecanismo del art. $155 \mathrm{CE}$, descansan en diferentes títulos legitimadores, sin perjuicio de que puedan resultar coincidentes algunas de las medidas que puedan llegar a adoptarse en uno y otro supuesto [STC 185/2016, FJ 17 b)].

En relación con la impugnación del art. 92.4 c) LOTC, que recoge la denominada ejecución sustitutoria al prever que el TC puede requerir la colaboración del Gobierno de la nación para asegurar mediante la ejecución sustitutoria el cumplimiento de sus resoluciones, el TC niega que esta pueda implicar que el Estado sustituya a la comunidad autónoma en el ejercicio de sus competencias, pues ello sí supondría una vulneración del principio de autonomía. Para el TC la aplicación de la ejecución sustitutoria, al igual que los demás instrumentos de ejecución del art. 92.4 LOTC, ha de cohonestarse y respetar siempre las previsiones constitucionales y nunca podrán dar lugar a la alteración de la posición institucional del Estado y de las comunidades autónomas, establecida en la CE y en los Estatutos de Autonomía. El TC no desarrolla la cuestión, pues argumenta que no le corresponde pronunciarse en aquel proceso constitucional sobre hipotéticas aplicaciones del precepto legal recurrido, pero parece que no sería posible que mediante la ejecución sustitutoria a la que se 
refiere el art. 92.4 c) LOTC, el Gobierno del Estado pudiera ejercer potestades, tales como la reglamentaria o la legislativa, que nuestro ordenamiento atribuye directamente a órganos de las comunidades autónomas.

En todo caso, el TC destaca que, aunque es cierto que el art. $92.4 \mathrm{c}$ ) LOTC únicamente prevé de manera expresa la posibilidad de requerir la colaboración del Gobierno de la nación, sin embargo, el precepto no impide que el TC pueda requerir la colaboración de otros órganos o Administraciones públicas, incluyendo, por tanto, la colaboración de las administraciones autonómicas o locales, en los supuestos en que opte por la ejecución sustitutoria como medida de ejecución ante incumplimientos de resoluciones dictadas en el ejercicio de su jurisdicción. Y esta posible ampliación del ámbito de los órganos cuya colaboración puede requerir el TC encuentra cobertura en el art. 92.2 LOTC, que le faculta con carácter general para «recabar el auxilio de cualquiera de las administraciones y poderes públicos para garantizar la efectividad de sus resoluciones que lo prestarán con carácter preferente y urgente».

2. En las SSTC 165/2016 (Pleno), de 4 de octubre, 182/2016 (Pleno), de 3 de noviembre, y 190/2016 (Pleno), de 15 de noviembre, el TC resuelve los recursos de inconstitucionalidad interpuestos por diversas comunidades autónomas contra la Ley 40/2010, de 29 de diciembre, de Almacenamiento Geológico de Dióxido de Carbono, por la que se transpone en nuestro ordenamiento la Directiva 2009/31/CE, de 23 de abril de 2009, del Parlamento Europeo y del Consejo, sobre Almacenamiento Geológico de Dióxido de Carbono.

Dos eran las cuestiones controvertidas: el encuadre de la norma en el orden constitucional de competencias y la constitucionalidad de que el Estado se reservase para sí determinadas competencias ejecutivas relacionadas con la concesión de licencias de almacenamiento.

En cuanto al encuadre, el TC considera que resulta irrelevante el mero dato de que los lugares de almacenamiento sean bienes de dominio público. También considera que resulta irrelevante que la UE haya dictado la Directiva 2009/31 en virtud de su título competencial sobre el medio ambiente. Tampoco es determinante que la finalidad última de la técnica de captación y almacenamiento de dióxido de carbono consista en luchar contra el cambio climático, reduciendo la emisión a la atmósfera de gases de efecto invernadero. Para el TC, atendidos el carácter, sentido y finalidad de las disposiciones que conforman la Ley 40/2010, el título competencial preferente para resolver la controversia competencial es el referido a la materia de minas sobre la que el Estado ostenta competencia sobre las bases (art. 149.1.25 CE).

Reconoce el TC que, aunque no pueda desconocerse que aquellos aspectos del régimen jurídico de la actividad de almacenamiento de dióxido de 
carbono que tengan como finalidad directa la protección del entorno, en razón a la peligrosidad potencial de aquella, podrían incardinarse en la materia de "medio ambiente», sin embargo la norma impugnada atiende fundamentalmente «a aquella dimensión vinculada con la gestión y emplazamiento de los yacimientos y demás estructuras subterráneas en los que se inyecta el dióxido de carbono", pues lo que hace la Ley impugnada es detallar la normativa sobre uso de las estructuras subterráneas que "por sus características permita retener naturalmente y en profundidad cualquier producto o residuo que en él se vierta o inyecte» [utilizando así precisamente la terminología del art. 3.1 B) de la Ley de Minas de 1973 y art. 5.1 del Reglamento General de la Minería, aprobado por Real Decreto 2857/1978, de 25 de agosto]. Se trata de normas sustantivas sobre el régimen de uso de los yacimientos minerales y demás recursos geológicos que forman el demanio minero, donde resulta determinante, según la sentencia, la aplicación de la técnica minera en los trabajos sujetos a la Ley, que deben ejecutarse mediante labores subterráneas o que requieren el empleo de cualquier clase de maquinaria, lo que justifica el encuadramiento competencial realizado.

En cuanto a quién deben corresponder las competencias ejecutivas, las comunidades autónomas recurrentes sostienen que deberían corresponderles todas las facultades administrativas relativas a la concesión de almacenamiento del dióxido de carbono, pues ostentan las competencias para el desarrollo y la ejecución de las bases del régimen minero establecidas por el Estado. Sin embargo, para el TC la opción del legislador estatal por un modelo de gestión centralizada de las concesiones de almacenamiento y no por un modelo de gestión autonómica se justificaría en el hecho de que los lugares de almacenamiento se encuentran interconectados con las redes de transporte y las instalaciones de captura, que pueden tener una clara dimensión supraterritorial, e incluso supranacional. Igualmente se justifica en el hecho de que el establecimiento de grandes instalaciones de combustión — grandes centrales térmicas- de competencia estatal vendrá íntimamente asociado a la obtención de concesiones de almacenamiento, y, por último, se justifica en la existencia de riesgos para la seguridad colectiva, que se asocian a la aplicación de una tecnología novedosa.

La saga jurisprudencial examinada supone que el TC haya identificado uno de aquellos supuestos, en teoría excepcionales, en los que la función ejecutiva le debe corresponder al Estado ${ }^{25}$.

25 El voto particular discrepante, firmado por los magistrados Asua Batarrita y Xiol Ríos, considera que el legislador estatal puede utilizar sus bases para condicionar el contenido y la forma de ejercer las competencias ejecutivas que corresponden a las comunidades 
3. En la STC 168/2016 (Pleno), de 6 de octubre, se plantea una colisión directa entre el contenido estatutario y el contenido de una normativa básica estatal.

El art. 6.1 del Estatuto de Autonomía de Asturias de 1981 garantiza la personalidad jurídica a los entes locales menores del Principado (las denominadas "parroquias rurales»). El art. 24 bis de la Ley Reguladora de las Bases del Régimen Local (LBRL), introducido por la Ley 27/2013, de 27 de diciembre, de Racionalización y Sostenibilidad de la Administración Local, niega la personalidad jurídica a los entes locales menores configurándolos como organizaciones municipales desconcentradas.

El recurrente, el Gobierno del Principado, impugna el art. 24 bis LBRL, pues considera que el legislador básico estatal de régimen local está obligado a respetar el derecho local estatutario; y, por tanto, solicita la declaración de inconstitucionalidad y nulidad del inciso «que carecerán de personalidad jurídica» del art. 24 bis, apartado 1 LBRL.

Sin embargo, el TC recuerda que conforme a la doctrina constitucional recogida en la STC 31/2010 (Pleno), de 28 de junio ${ }^{26}$, el Estatuto de Autonomía puede contener las líneas fundamentales del régimen local en el ámbito territorial de la comunidad autónoma, "pero solo con el fin de "vincular al legislador autonómico" y respetando en todo caso la competencia básica que al Estado corresponde en la materia en virtud de la reserva del art. 149.1.18 CE, por cuanto la expresión "bases del régimen jurídico de las Administraciones públicas" engloba a las Administraciones locales» [SSTC 41/2016 (Pleno), de 3 de marzo, FJ 3 a); 31/2010, FFJJ 36 y 37, y 103/2013 (Pleno), de 25 de abril, FJ 4]. De modo que las disposiciones de derecho local incluidas en un Estatuto de Autonomía no

autónomas, pero no alterar la distribución competencial atribuyendo la ejecución directamente al Estado. Señala el voto particular su oposición a la generalización acrítica e incondicionada de la línea jurisprudencial que admite excepcionalmente la adopción de actos de ejecución como parte de lo básico. Para los magistrados discrepantes, la admisión de que lo básico puede encontrarse en actos de ejecución es una línea jurisprudencial originalmente desarrollada para justificar el ejercicio de facultades ejecutivas concretas por organismos muy específicos como el Banco de España, esto es, en el ámbito de las «bases de la ordenación de crédito, banca y seguros» (art. 149.1.11 CE). Denuncia el voto particular que en la STC 31/2010 (Pleno), de 28 de junio (FJ 60), el TC habría reformulado la doctrina previa en unos términos tan generales e incondicionales que habrían provocado el entendimiento de que la competencia estatal sobre las bases incluye con toda naturalidad la posibilidad de dictar actos de ejecución en cualquier materia, dando así lugar a una alteración de la distribución competencial.

26 Reseñada, por lo que se refiere a las previsiones del EAC en materia de régimen local, en REDC, núm. 90, 2010, pp. 213-215. 
pueden vincular al legislador estatal del régimen local ni «impedir de ninguna manera el ejercicio de esa competencia estatal» (STC 31/2010, FJ 37).

Para el TC, como consecuencia de la adopción de la Ley 27/2013, se habría producido una contradicción sobrevenida entre la legislación básica estatal — dictada legítimamente al amparo del art. 149.1.18 CE- y una norma estatutaria - que venía expresando una línea fundamental del régimen local de una concreta comunidad autónoma (art. 147.1 CE), y que era coincidente con la normativa básica existente hasta la Ley 27/2013.

La consecuencia de la doctrina recogida en la STC 31/2010 — en relación con la posibilidad de que determinados contenidos del régimen local puedan estar simultáneamente en el Estatuto y en la legislación básica, estableciéndose como regla que lo establecido en aquel debe respetar las basessurge ahora con toda su crudeza, pues, mientras que en el supuesto resuelto por la STC 31/2010 no existía contradicción entre ambas normas, en el supuesto resuelto por la STC 168/2016 sí se da tal contradicción. En efecto, resultando plenamente aplicable en el ámbito territorial del Principado de Asturias la legislación básica, esta pasa a tener una suerte de prevalencia sobre el Estatuto de Autonomía, pues para la STC 168/2016 un Estatuto de Autonomía no puede suponer que las nuevas bases dejen de operar como mínimo común normativo, esto es, que sean inaplicables en una comunidad autónoma por virtud del derecho local incluido en su Estatuto.

Ciertamente, la consecuencia de la aplicación de la doctrina recogida en su día en la STC 31/2010 es una cierta degradación de la posición del Estatuto en el sistema de fuentes. Para evitarla, quizá se podría haber explorado en su momento, bien la opción de distribuir el contenido del régimen local entre el legislador básico y el estatutario (por ejemplo, reservando a este determinados aspectos relativos a los entes locales menores), bien la opción de haber considerado posible que las bases no vinculasen de forma homogénea a todos los territorios dando así prevalencia al Estatuto de Autonomía sobre las bases en determinados aspectos.

4. La STC 177/2016 (Pleno), de 20 de octubre, resuelve la impugnación planteada contra la Ley 28/2010, de 3 de agosto, del Parlamento de Cataluña por la que se prohíben las corridas de toros y los espectáculos con toros que incluyan la muerte del animal. El TC encuadra la prohibición autonómica en el ejercicio de las competencias atribuidas a la comunidad autónoma en materia de protección de los animales [art. 116.1 d) EAC] y en materia de espectáculos públicos (art. 141.3 EAC). No obstante el encuadre realizado, señala el TC que el ejercicio autonómico de tales competencias ha de cohonestarse con el ejercicio de las competencias estatales en materia de cultura. 
El TC se refiere, por un lado, a la competencia recogida en el art. 149.2 $\mathrm{CE}$, que dispone, sin perjuicio de las competencias que podrán asumir las comunidades autónomas, el servicio de la cultura como deber y atribución esencial del Estado, y, por otro, a la competencia recogida en el art. 149.1.28 $\mathrm{CE}$, que reserva al Estado la competencia en materia de defensa del patrimonio cultural, artístico y monumental español contra la exportación y la expoliación. Sin embargo, posteriormente solo desarrolla aquello que tiene que ver con la primera de las competencias estatales referidas, pues señala el TC que el Estado, en el ejercicio de sus competencias derivadas del art. 149.2 CE, ha adoptado un conjunto de normas - tanto la Ley 18/2013, de 12 de noviembre, para la Regulación de la Tauromaquia como Patrimonio Cultural, como la Ley 10/2015, de 26 de mayo, para la Salvaguardia del Patrimonio Cultural Inmaterial-, de las que se infiere que el Estado ha declarado formalmente la tauromaquia como patrimonio cultural.

Para el TC la norma autonómica, al incluir una medida prohibitiva de las corridas de toros en ejercicio de sus competencias en materia de protección de los animales y en materia de espectáculos públicos, ha menoscabado, sin embargo, las competencias estatales en materia de cultura, en cuanto ha impedido en Cataluña el ejercicio de la competencia estatal dirigida a conservar esa tradición cultural, ya que, directamente, hace imposible dicha preservación.

Dos cuestiones problemáticas se plantean en la resolución del TC. La primera tiene que ver con el alcance de la competencia sobre cultura. Como señala el voto particular firmado por los magistrados Asua Batarrita y Valdés Dal-Ré, «hasta la fecha el art. 149.2 CE no había sido interpretado como un título legislativo». Para los magistrados discrepantes, la competencia sobre cultura es una competencia estatal no normativa, $y$, por tanto, sin capacidad de desplazar a las competencias autonómicas - incluso exclusivas- que puedan recaer sobre el mismo objeto, pues de lo contrario recortaría enormemente las competencias autonómicas tanto en materia de cultura como en otras materias (por ejemplo, como ocurre en el presente caso, espectáculos públicos y protección animal). Bajo esta perspectiva, los títulos competenciales que amparan la acción legislativa del Estado están en el art. 149.1 CE y no en el art. 149.2 CE. Entenderlo de otro modo llevaría a desfigurar el carácter de competencia concurrente entre las comunidades autónomas y el Estado que en el marco del art. 149.2 CE adquiere la protección de la cultura como señala igualmente el magistrado Xiol Ríos en su voto particular. Así, en efecto, de la dicción del precepto constitucional parece que se trataría de una suerte de competencia compartida, pero de carácter complementario, es decir, una competencia de fomento de la cultura, que tendría como límite la imposibilidad de armonizar las decisiones adoptadas por las comunidades autónomas. 
La segunda cuestión problemática es la referida a la figura de la inconstitucionalidad por menoscabo. El TC parece estar desarrollando en este punto un nuevo límite más allá del límite propiamente competencial. Un límite que evoca, sin explicitarlo, aquel que cabe derivar del principio de lealtad y que supone la obligación de ejercer la propia competencia con consideración hacia la competencia del otro. Pero límite que en este caso podría suscitarse sí realmente concurre, pues el ejercicio de la competencia estatal de protección (leyes estatales de 2013 y 2015) ha sido posterior al ejercicio de la competencia autonómica de prohibición (ley autonómica de 2010), y la lealtad como principio que limita el ejercicio competencial propio podría ser considerado igualmente como límite al ejercicio de la competencia estatal, como parece subyacer en la argumentación del voto particular del magistrado Xiol Ríos que no obstante propone la ponderación como criterio para afirmar la prioridad competencial de la decisión autonómica.

5. La STC 203/2016 (Pleno), de 1 de diciembre ${ }^{27}$, resuelve por primera vez una cuestión prejudicial sobre la validez de una norma foral fiscal, una nueva competencia atribuida al TC por la reforma de la LOTC de 2010 y que ya fue declarada constitucional en la STC 118/206 (Pleno), de 23 de junio ${ }^{28}$. La controversia que resuelve la STC 203/2016 se plantea en relación con el art. 30.2 de la Norma Foral 10/2006, de 29 de diciembre, Reguladora del Impuesto sobre la Renta de las Personas Físicas del Territorio Histórico de Guipúzcoa, por posible infracción del art. 3.a) de la Ley 12/2002, de 23 de mayo, por la que se aprueba el Concierto Económico con la Comunidad Autónoma del País Vasco.

Para el órgano judicial proponente de la cuestión, el apartado 2 del art. 30 puede ser contrario al art. 3 a) de la Ley 12/2002, de 23 de mayo, pues, con independencia del nomen iuris usado por la norma foral (estimación objetiva), está regulando una suerte de estimación directa «impropia» que no respeta las características intrínsecas que determinan este método en la Ley General Tributaria. El TC tras comparar el concepto de estimación objetiva contenido en esta con el recogido en la norma foral estima la cuestión y declara la inconstitucionalidad y nulidad del precepto impugnado.

Desde el punto de vista de la organización territorial del Estado, interesa examinar alguna de las afirmaciones que se realizan en la STC 203/2016. Así, en efecto, el TC recuerda, en primer lugar, la doctrina sentada en la STC 118/2016, donde subrayó que son un parámetro inmediato o directo de la

27 Véase supra, p. 346.

28 Reseñada en REDC, núm. 108, 2016, pp. 235-237 y 241-242. 
validez de las normas forales fiscales, además de la CE, tanto el Estatuto de Autonomía, como el Concierto, al ser normas ordenadoras de las relaciones tributarias entre el Estado y los territorios históricos; y dónde también señaló que «son parámetro mediato o indirecto del enjuiciamiento de aquella validez, por expresa remisión de la Ley del Concierto, tanto las normas estatales reguladoras de los diferentes tributos que configuran "la estructura general impositiva del Estado" [art. 2.1.2 de la Ley del Concierto Económico] como la Ley General Tributaria [art. 3 a) de la Ley del Concierto Económico]».

No obstante lo anterior, es de destacar una importante matización a la afirmación recogida en la STC 118/2016 de que el régimen tributario foral deba ser reflejo del régimen tributario estatal, pues el TC en la STC 203/2016 recuerda un relevante límite a la posibilidad de acudir a las normas estatales reguladoras de los diferentes tributos como parámetro mediato de constitucionalidad de las normas forales fiscales: ello únicamente podrá hacerse en la medida en que la competencia de los territorios forales para mantener, establecer, regular y gestionar su propio régimen tributario deba atender a la estructura general impositiva del Estado [art. 41.2 a) EAPV y art. 2.1.2 de la Ley del Concierto Económico], pues aquellos territorios han de establecer unos impuestos en los que sea «identificable la imagen de los que integran el sistema tributario estatal» [SSTC 110/2014 (Pleno), de 26 de junio, FJ 3; y 118/2016, FJ 2 a)]; sin que quepa exigir, sin embargo, señala el TC en la STC 203/2016, «una identidad regulatoria completa que llegue al punto de considerar que cualquier elemento contenido en la norma estatal reguladora de cada una de las figuras tributarias que integran dicho sistema sea un elemento configurador de la estructura general impositiva del Estado».

El TC excluye, así, la posibilidad de que las normas estatales reguladoras de los diferentes tributos se constituyan en su integridad en un parámetro de la conformidad de las normas forales fiscales con la CE, matizando de esta forma algunas interpretaciones excesivas en relación con los límites del territorio foral para poder adoptar normas fiscales que se habrían hecho del alcance de la STC 118/2016, FJ 2 b).

6. La STC 204/2016 (Pleno), de 1 de diciembre ${ }^{29}$, ha ampliado el alcance de la revocación de la doctrina tradicional del propio TC sobre la prevalencia. Una revocación ya comenzada en la STC 102/2016 (Pleno), de 25 de mayo ${ }^{30}$.

En la STC 102/2016, el TC había considerado que debía apartarse de la doctrina tradicional que proscribía a los jueces ordinarios la aplicación

\footnotetext{
29 Véase supra, p. 339.

30 Reseñada en REDC, núm. 108, 2016, pp. 237-238; 239-241 y 250-252.
} 
prevalente de las bases del Estado frente a una ley autonómica en un caso como el que daba origen a aquella cuestión de inconstitucionalidad «en que la legislación autonómica no ha hecho sino reproducir la legislación básica, y ésta se modifica después en un sentido incompatible con aquella legislación autonómica». Se trataba de un caso de «inconstitucionalidad indirecta o mediata» (FJ 2), en el que la legislación autonómica no había hecho sino reproducir la legislación básica, y esta se había modificado después en un sentido incompatible con aquella legislación autonómica (FF JJ 2 y 3). Concurriendo además la característica de que el TC ya se había pronunciado en favor del carácter básico de la regulación estatal (FJ 6).

Se trataría de una excepción de la obligación de plantear una cuestión de inconstitucionalidad cuando se diese una suerte de supuesto de acto aclarado por parte de la doctrina previa del propio TC que ya hubiese declarado el carácter básico de la norma estatal. Cumplidas las características enunciadas los órganos judiciales tendrían la capacidad, o más bien la obligación, de inaplicar las leyes autonómicas cuando el TC hubiese proporcionado una orientación suficiente para ello.

Aparentemente la revocación de la doctrina previa que desembocaba en la inadmisión de las cuestiones de inconstitucionales planteadas solo se daría en aquellos supuestos en los que concurriesen las concretas circunstancias que se daban en el asunto resuelto por la STC 102/2016. Circunstancias que concurrían en los asuntos resueltos por las SSTC 116/2016 (Sala Primera), de 20 de junio, y 127/2016 (Pleno), de 7 de julio, y por el ATC 167/2016 (Pleno), de 4 de octubre.

Sin embargo, en el asunto resuelto por la STC 204/2016, el TC da un paso más en la ampliación de la capacidad de los jueces y tribunales ordinarios para inaplicar una ley autonómica utilizando la regla de la prevalencia recogida en el art. 149.3 de la CE, pues obliga a tal utilización incluso en los supuestos en los que se constata que la comunidad autónoma no reprodujo en su momento la legislación básica, dado que tal legislación no existía en el momento de dictarse la norma autonómica. Pero, asimismo, y a pesar de que no se afirme explícitamente en la STC 204/2016, en el asunto que esta resuelve tampoco concurriría una segunda circunstancia presente en la STC 102/2016 y su progenie y es la circunstancia de que el TC ya se hubiese pronunciado en favor del carácter básico de la regulación estatal.

A pesar de que no concurren las características presentes en los asuntos previamente resueltos, el TC afirmará, sin mayor ilustración, que «la razón de decidir de aquella Sentencia [la 102/2016] sirve para resolver también el presente proceso constitucional», pues de acuerdo con la STC 204/2016 «en ambos casos se trata de una ley autonómica a la que, en el momento en que se dictó, no podía 
imputarse vicio alguno de inconstitucionalidad, y que, sin embargo, deviene incompatible con una ley básica del Estado aprobada con posterioridad».

Basta, por tanto, con que se trate de un caso de «inconstitucionalidad mediata sobrevenida" para que el órgano judicial deba, salvo que tenga dudas en relación con la constitucionalidad de la norma estatal básica, dar preferencia, en aplicación de la regla de prevalencia del art. 149.3 CE, a la norma estatal y desplace la norma autonómica que la contradiga. Ya no es posible el planteamiento de la cuestión de inconstitucionalidad frente a la norma autonómica, pues el juez debe inaplicarla. Se produce, como señalan los votos particulares, «la generalización incondicionada de la doctrina de la prevalencia».

Los votos particulares, uno firmada por la magistrada Asua Batarrita y otro por el magistrado Martínez-Vares García —en este punto es de destacar que a la misma velocidad que el número de magistrados discrepantes había ido en aumento, desde uno, en la STC 102/2016, a cinco, en la STC 127/2016, habría disminuido después, a dos en la STC 204/2016-, señalan dos consecuencias de reconocer/imponer la capacidad/obligación de los órganos judiciales de aplicar la prevalencia a los supuestos de inconstitucionalidad mediata sobrevenida — una obligación en cuanto que bajo la nueva doctrina no parece que el órgano judicial pueda plantear la cuestión de inconstitucionalidad como una alternativa a su capacidad de inaplicar la ley autonómica, pues, precisamente, las sentencias finalizan con un fallo de inadmisión de las cuestiones planteadas por considerar que el juicio de aplicabilidad que el órgano judicial debe hacer en aplicación del art. 149.3 CE, hace que no se cumpla ya la condición para plantear una cuestión ex art. $163 \mathrm{CE}$, que se trate de una ley aplicable al caso-: un riesgo de mayor inseguridad jurídica ${ }^{31}$ y una falta de preservación de la posición de los Parlamentos autonómicos ${ }^{32}$.

31 En lo que se refiere a la inseguridad jurídica, esta provendría fundamentalmente del riesgo de contradicciones entre los diversos órganos judiciales a la hora de determinar la compatibilidad de las leyes autonómicas con la normativa básica estatal. Con la nueva doctrina se deja la interpretación y aplicación de la distribución de competencias mediante la técnica bases-desarrollo en manos de los órganos judiciales ordinarios, los cuales una vez han constatado el carácter básico de la norma estatal, deben realizar el juicio de compatibilidad de la ley autonómica con las bases estatales sin poder contar para realizarlo con las orientaciones de un Tribunal centralizado. Ello puede dar lugar a una pluralidad de interpretaciones en relación con el juicio de compatibilidad señalado.

32 En lo que se refiere a la incapacidad de los Parlamentos autonómicos de alegar con carácter previo a que sus leyes sean inaplicadas, esta se produce por el hecho de que en los pleitos de los que conocen los Jueces ordinarios, el Parlamento autonómico, o incluso su Gobierno, no son parte en el litigio. Así con anterioridad a la nueva doctrina de la 
La obligación de aplicar la regla de la prevalencia por parte de los jueces ordinarios se ha establecido, de momento, por la doctrina del TC solo para los supuestos de inconstitucionalidad mediata sobrevenida. Sin embargo, de la doctrina del propio TC no se deriva razón alguna que no permitiera extender tal obligación a aquellos supuestos de inconstitucionalidad mediata no sobrevenida sino originaria ${ }^{33}$.

\section{ORGANIZACIÓN DE LOS PODERES PÚBLICOS}

1. En este apartado de la crónica, cabe destacar la STC 191/2016 (Pleno), de 15 de noviembre, que resuelve el recurso de inconstitucionalidad interpuesto por una fracción de grupo parlamentario contra diversos preceptos de la Ley Orgánica del Poder Judicial (LOPJ), en la redacción dada por la Ley Orgánica 4/2013, de 28 de junio, de Reforma del Consejo General del Poder Judicial (CGPJ). Los diputados recurrentes fundaban la impugnación de esta reforma en la premisa de que esta supone una reducción notoria de las competencias del CGPJ e introduce limitaciones y obstrucciones a su funcionamiento, sobre todo en materia presupuestaria, susceptible de situar a los miembros del CGPJ en una relación de clara subordinación con respecto al poder ejecutivo, lo que resulta contrario al art. $122 \mathrm{CE}$.

Tras depurar el objeto del recurso (FF JJ 2 y 3), el TC entra a examinar los concretos preceptos impugnados, para descartar todas las tachas formuladas por los recurrentes, si bien acudiendo a lo que se califica en la propia STC 191/2016 como interpretación de conformidad, en lo que se refiere al nuevo art. 564 LOPJ, a cuyo tenor los miembros del CGPJ no tienen deber alguno de comparecer ante las Cámaras por razón de sus funciones, con la única salvedad, en su caso, de la comparecencia del presidente del Tribunal Supremo ante las Cortes Generales para responder a las preguntas que se le formulen acerca de la memoria que el CGPJ ha de remitir anualmente a las Cortes sobre el estado, funcionamiento y actividades del propio CGPJ y de los juzgados y tribunales (art. 563 LOPJ). El TC concluye (FJ 6) que el precepto impugnado no vulnera la reserva constitucional a favor de los Reglamentos de cada una de las Cámaras que componen las Cortes Generales (art. 72.1 CE); tampoco infringe el art. 76.2 CE, que establece la obligación de comparecer, a requerimiento de

prevalencia la representación de la comunidad autónoma, tanto el Gobierno como el Parlamento, tenía la capacidad de intervenir ex art. 37.3 LOTC en el proceso ante el TC por el que se resolvía la cuestión de inconstitucionalidad frente a la ley autonómica.

33 Tomás de la Quadra-Salcedo Janini. 
las Cámaras, ante las comisiones de investigación que estas puedan instituir, pues el objeto del art. 564 LOPJ es regular un aspecto general de las relaciones generales u ordinarias entre las Cortes y el CGPJ, cuya disciplina nada dice respecto de lo que pudiera eventualmente derivar del ejercicio por las Cámaras de la función extraordinaria u ocasional que desempeñan por medio de sus Comisiones de investigación; finalmente, tampoco vulnera el art. $109 \mathrm{CE}$, que permite a las Cámaras y sus Comisiones recabar la información y ayuda que precisen del Gobierno y de cualesquiera autoridades del Estado y de las comunidades autónomas.

2. Sobre el alcance de la función de las Mesas de las Asambleas legislativas de calificación y admisión a trámite de las iniciativas parlamentarias se pronuncia la STC 212/2016 (Pleno), de 15 de diciembre, para confirmar un criterio que ya se había mantenido en sentencias precedentes, dictadas también, como la STC 212/2016, en relación con la Mesa de las Cortes Valencianas (SSTC 29/2011 y 158/2014). A saber: que la admisión a trámite de una iniciativa parlamentaria es función que corresponde estrictamente a la Mesa de la Cámara, de conformidad con las facultades de calificación y admisión de los escritos de índole parlamentaria que le atribuye el propio Reglamento, por lo que no cabe escudarse en el parecer desfavorable de la Junta de Portavoces para inadmitir a trámite una iniciativa, so pena de incurrir en vulneración del derecho del diputado autor de la misma a ejercer las funciones representativas con los requisitos que señalan las leyes $(\operatorname{art} .23 .2 \mathrm{CE})^{34}$.

\section{DERECHOS FUNDAMENTALES}

1. Durante este cuatrimestre, entre otros muchos pronunciamientos, el TC ha tenido ocasión de pronunciarse sobre dos temas que deben ser destacados, uno por su potencial impacto en las relaciones entre los particulares y los bancos, y el otro, por su novedad jurisprudencial. El primero de ellos, resuelto en la STC 148/2016 (Sala Segunda), de 19 de septiembre, se refiere a la denominada «cláusula suelo» de los préstamos hipotecarios y su impugnación por los particulares en la vía judicial; el segundo, abordado en la STC 226/2016 (Pleno), de 22 de diciembre, resuelve el conflicto entre el derecho a la libertad de expresión y el derecho de asociación, en el ámbito de un partido político. A continuación, se comenta una selección de las sentencias que se han considerado más interesantes.

34 Herminio Losada González. 
2. En relación con el art. 14 CE, debe ser destacada la STC 162/2016 (Sala Primera), de 3 de octubre, en la que se analizó la posible vulneración del principio de no discriminación por el hecho de que no se reconociera a la demandante de amparo el complemento de destino obtenido mientras disfrutaba de las licencias y permisos asociadas a su maternidad. Recuerda el TC la doctrina del TJUE establecida en su Sentencia, de 16 de febrero de 2006, en la que declaró contrario al derecho europeo una normativa nacional que no reconozca a una trabajadora que se encuentre en permiso de maternidad los mismos derechos reconocidos a otros aspirantes aprobados en el mismo procedimiento de selección, en lo que se refiere a las condiciones de acceso a la función pública. Señala el TC que la aplicación del art. 245 del Reglamento 2/2011 de la Carrera Judicial ${ }^{35}$ fue lo que llevó, tanto a la Administración como al órgano judicial, a considerar que la demandante de amparo, magistrada a la que habían correspondido dos nuevos destinos en la ciudad de Bilbao - pero en situación de baja por encontrarse disfrutando de diversas licencias en relación con la maternidad-, no tenía derecho a percibir el complemento de destino si antes no había procedido a tomar posesión de este. Reprocha el TC que no se tuviera en cuenta, sin embargo, para llegar a tal decisión, lo dispuesto en la Ley Orgánica 3/2007, de 22 de marzo, para la Igualdad Efectiva de Mujeres y Hombres ${ }^{36}$. Se ha de tener en consideración,

35 Dicho precepto establece que «las licencias y permisos, incluido el de vacaciones, no se verán afectados por los traslados o promoción de los jueces y magistrados. Producido el traslado, el plazo posesorio empezará a contarse a partir del día siguiente al de finalización del permiso o licencia. El cese en el destino, a efectos administrativos, tendrá efectos al día siguiente de la publicación en el "Boletín Oficial del Estado" de la resolución por la que se disponga el traslado o promoción, salvo que en la resolución que lo motive se establezca otra cosa».

36 En concreto, el art. 51 de la citada Ley, que encabeza el capítulo I del título V dedicado al principio de igualdad en el empleo público, y que establece los criterios de actuación de las Administraciones públicas, dispone que «las Administraciones públicas, en el ámbito de sus respectivas competencias y en aplicación del principio de igualdad entre mujeres y hombres, deberán: a) Remover los obstáculos que impliquen la pervivencia de cualquier tipo de discriminación con el fin de ofrecer condiciones de igualdad efectiva entre mujeres y hombres en el acceso al empleo público y en el desarrollo de la carrera profesional; b) Facilitar la conciliación de la vida personal, familiar y laboral, sin menoscabo de la promoción profesional; [...] f) Establecer medidas efectivas para eliminar cualquier discriminación retributiva, directa o indirecta, por razón de sexo». Y ello tras definir, en su art. 3, el principio de igualdad de trato entre mujeres y hombres como «la ausencia de toda discriminación, directa o indirecta, por razón de sexo, y, especialmente, las derivadas de la maternidad, la 
dice la Sentencia, que los permisos y licencias legalmente establecidos con motivo de la gestación y posterior alumbramiento, conectados con la protección de la salud e integridad del feto y de la madre, no pueden quedar equiparados al resto de permisos y licencias. El principio de no discriminación por razón de sexo obliga a compensar las desventajas que el embarazo, al incidir de forma exclusiva sobre las mujeres a diferencia del hombre, pueden provocar en sus derechos económicos y profesionales. Ni la Administración ni el órgano judicial tuvieron en cuenta que la condición biológica y la salud de la mujer trabajadora han de ser compatibles con la conservación de los derechos profesionales, sin que la maternidad pueda suponer ninguna desventaja. Con tal decisión, concluye el TC, la Administración no atendió a los principios del ordenamiento jurídico que imponen a los poderes públicos promover no solo la igualdad formal, sino también la igualdad real y efectiva. Se consideró vulnerado el art. $14 \mathrm{CE}$.

3. La STC 226/2016 (Pleno), de 22 de diciembre, aborda un novedoso problema constitucional al resolver el conflicto planteado entre el derecho de asociación, en el marco de un partido político, y la libertad de expresión de sus afiliados. La recurrente en amparo - militante del Partido Socialista Obrero Español (PSOE) - publicó una carta al director en un diario criticando el hecho de que unos días antes, la comisión ejecutiva regional de la federación socialista asturiana del PSOE acordara solicitar a la comisión federal de listas del partido la suspensión del proceso de primarias para elegir al candidato a la alcaldía de Oviedo ${ }^{37}$. Como consecuencia del contenido de dicha carta, la actora fue sancionada con la suspensión de militancia por veinte meses, en aplicación del art. 46 c) del Reglamento de Afiliados y Afiliadas, por la comisión de dos faltas muy graves tipificadas en su art. 44 i) [«menoscabar la imagen de los cargos públicos o instituciones socialistas»] y k) [«actuación en contra de acuerdos expresamente adoptados por los órganos de dirección del Partido»]. En síntesis, la demandante de amparo estimaba que el ejercicio de la potestad disciplinaria por el mencionado partido, posteriormente confirmada en sede judicial, vulneró su derecho fundamental a la libertad de expresión. Precisa de inicio el TC que, aunque la infracción de derechos fundamentales invocados

asunción de obligaciones familiares y el estado civil» y declarar en el art. 8 que la discriminación por embarazo o maternidad «constituye discriminación directa por razón de sexo todo trato desfavorable a las mujeres relacionado con el embarazo o la maternidad".

37 El extenso contenido de la carta hace imposible su reproducción en la presente crónica, por lo que remitimos al lector al texto de la sentencia. 
tiene su origen en la actuación privada de un partido político que tiene la naturaleza de asociación ex art. $22 \mathrm{CE}$, dicha infracción también ha sido reprochada por la recurrente a los órganos judiciales, en la medida en que estos no la repararon al confirmar la sanción disciplinaria del partido. Señala, a continuación, que, si bien la libertad de expresión consagrada en el art. $20 \mathrm{CE}$ es, como la mayor parte de los derechos fundamentales, preferentemente un derecho de garantía frente a los poderes públicos, su contenido se extiende también a las relaciones entre particulares y, por tanto, puede reivindicarse también frente a estos, aunque en ese ámbito el contenido y ejercicio del derecho se someta a unos límites específicos. Tras recordar su doctrina sobre la libertad de expresión y sus límites y del derecho a la asociación, considera el TC que un partido político puede reaccionar utilizando la potestad disciplinaria de que dispone según sus estatutos frente a un ejercicio de la libertad de expresión de un afiliado que resulte gravemente lesivo para su imagen pública. Quienes ingresan en una asociación, afirma el TC, han de conocer que su pertenencia les impone una mínima exigencia de lealtad, si bien el tipo y la intensidad de las obligaciones que dimanen de la relación voluntariamente establecida vendrán caracterizados por la naturaleza específica de cada asociación. En el supuesto concreto de los partidos políticos, ha de entenderse que los afiliados asumen el deber de preservar la imagen pública de la formación política a la que pertenecen y de colaboración positiva para favorecer su adecuado funcionamiento. En cuanto al ámbito de la libertad de expresión, la exigencia de colaboración leal, según el TC, se traduce igualmente en una obligación de contención en las manifestaciones públicas incluso para los afiliados que no tengan responsabilidades públicas, tanto en las manifestaciones que versen sobre la línea política o el funcionamiento interno del partido como en las que se refieran a aspectos de la política general en lo que puedan implicar a intereses del propio partido. Al valorar las expresiones vertidas por la recurrente, considera el TC que pueden ser consideradas provocativas e hirientes, ya que presentan a los órganos de dirección del partido desde una perspectiva negativa y hostil que compromete seriamente la consideración pública del partido en cuestión. En opinión del TC, la libertad de expresión de un afiliado no ampara expresiones que puedan considerarse atentatorias contra la imagen externa del partido y de quienes lo dirigen y que induzcan a la opinión pública a considerar que la propia organización no respeta el mandato constitucional de responder a una organización y funcionamiento democrático. A la vista de la naturaleza de las expresiones empleadas, así como de las acusaciones explícitas e implícitas contenidas en el artículo de opinión, debe reconocerse, afirma la Sentencia, que el partido político, al imponer a la recurrente la sanción de suspensión temporal de militancia, ejerció de forma legítima su potestad disciplinaria que se fundamenta en la 
facultad de auto organización constitucionalmente reconocida. La Sentencia cuenta con dos opiniones discrepantes.

4. Sobre el art. $23 \mathrm{CE}$, se han dictado varias sentencias que merecen ser reseñadas. En la STC 143/2016 (Sala Primera) ${ }^{38}$, de 19 de septiembre, el objeto del amparo era determinar si los acuerdos de la Mesa de la Junta General del Principado de Asturias, por los que se establecía el cronograma para la tramitación del proyecto de ley del Principado de Presupuestos Generales para 2013, lesionaron el derecho de representación política del grupo parlamentario recurrente por haberse establecido unos plazos inferiores a los previstos reglamentariamente, limitando con ello el ejercicio de las funciones de examen, enmienda, aprobación y control que conforma el ius in officium de los representantes parlamentarios. Recuerda el TC que, por lo que se refiere a las decisiones de las Mesas de las Cámaras referidas al acortamiento de los plazos de tramitaciones legislativas, la jurisprudencia constitucional ha declarado que una reducción del tiempo de tramitación no priva a las Cámaras del ejercicio de su función legislativa, ya que incide solo sobre su cronología; ni tiene por qué traducirse en merma alguna de los principios constitucionales que han de informar el procedimiento legislativo en cuanto procedimiento de formación de la voluntad del órgano; tal reducción del tiempo de tramitación solo podrá llegar a tener relevancia constitucional cuando su alcance sea de tal magnitud que haya alterado de forma sustancial el proceso de formación de la voluntad de una Cámara. Por tanto, analiza a continuación el cronograma aprobado por la Mesa para la tramitación del proyecto de Ley de Presupuestos Generales para 2013 ${ }^{39}$.

38 Comentada también supra p. 348.

39 El proceso seguido se puede resumir en lo siguiente: (i) el Consejo de Gobierno del Principado de Asturias remitió a la Junta General el 4 de diciembre de 2012 el proyecto de ley del Principado de Asturias de Presupuestos Generales para 2013 y la Mesa de la Junta General aprobó, mediante acuerdo de 5 de diciembre de 2012, el cronograma para la tramitación de dicho proyecto con una reducción de plazos respecto de los establecidos en el procedimiento ordinario, con expresa invocación del art. 120.2 RJG, que establece que la Mesa de la Cámara, salvo casos excepcionales, no podrá reducir los plazos establecidos en el Reglamento en menos de la mitad. (ii) El Grupo Parlamentario Foro Asturias formuló una solicitud de reconsideración, invocando el art. 23.2 CE, argumentando que el Reglamento de la Cámara no permite una reducción de plazos tan radical como la acordada. (iii) La Mesa de la Cámara desestimó la solicitud, argumentando, por lo que se refiere a la aprobación del cronograma, que, si bien los plazos son perentorios, es una práctica habitual en el Parlamento asturiano, siendo similares los plazos previstos y aprobados 
Rechaza las lesiones aducidas el TC, de un lado, porque considera que no se ha incumplido la legalidad parlamentaria, ya que, si bien el reglamento prohíbe la tramitación urgente del proyecto de ley de presupuestos, la Mesa sustentó los acuerdos impugnados en una previsión reglamentaria que permite la reducción de plazos en supuestos excepcionales (en este caso, la necesidad de que el presupuesto se aprobara antes del inicio del nuevo ejercicio, habiendo sido remitido el proyecto de ley el 4 de diciembre de 2012), lo que no comporta un exceso interpretativo del reglamento. Por otra parte, el acortamiento de los plazos no tuvo una incidencia significativa en el núcleo esencial del ius in officium de los parlamentarios, ya que no han quedado acreditadas limitaciones al ejercicio de las funciones representativas a causa de los plazos; es más, constata el TC que el grupo recurrente participó activamente en el procedimiento.

En la STC 199/2016 (Sala Primera), de 28 de noviembre, la cuestión suscitada en el recurso de amparo se contraía a determinar si la decisión del presidente de la sesión constitutiva del Parlamento de Andalucía, por la que se proclamó a los tres secretarios de la Mesa del Parlamento, vulneró el derecho de la demandante a acceder en condiciones de igualdad a las funciones y cargos públicos reconocido en el art. 23.2 CE, en relación con el derecho de los ciudadanos a participar en los asuntos públicos a través de sus representantes, garantizado en el art. 23.1 CE. La recurrente, diputada del Parlamento andaluz y candidata propuesta por el grupo parlamentario del Partido Popular (PP) al cargo de secretaria de la Mesa, alegaba que el presidente de la sesión constitutiva se apartó del procedimiento establecido en los arts. 33 y 34 del Reglamento del Parlamento de Andalucía (RPA), al que remite expresa y taxativamente el art. 3.2 RPA. De acuerdo con él resultaría obligado proclamar como secretarios de la Mesa a aquellos diputados que, por orden correlativo, hubiesen obtenido

en el cronograma del proyecto de ley de presupuestos de los años 2009, 2010 y 2011, entre otros. Posteriormente, la Junta General en su escrito de alegaciones afirmaba que también queda justificada en este caso esa situación de excepcionalidad que permite una reducción de plazos en la tramitación en que el mecanismo de prórroga presupuestaria lo es únicamente en sus créditos iniciales y no en los consolidados, y que, en este caso, además, el Principado de Asturias se había pasado ya todo el año 2012 en situación de prórroga presupuestaria en relación con el presupuesto de 2011. Igualmente, destaca el hecho de que se había aprobado la Ley Orgánica 2/2012, de 27 de abril, de Estabilidad Presupuestaria y Sostenibilidad Financiera, que fijaba nuevas reglas preceptivas para la elaboración y aprobación de los presupuestos autonómicos que el elaborado para 2011 y ya prorrogado durante 2012 no habían podido prever. 
la mayoría de votos ${ }^{40}$. Tras traer a colación la doctrina constitucional sobre los derechos fundamentales invocados, el TC afirma que no cabe duda de que corresponde a los diputados el derecho a formar parte de la Mesa de la Cámara con los requisitos que el Reglamento de esta determine, y que dicha facultad pertenece al núcleo de la función representativa parlamentaria. Constata el TC que el procedimiento previsto en los arts. 33 y $34 \mathrm{RPA}$, en lo que atañe a los tres secretarios, consiste en que cada diputado escribirá un solo nombre en la papeleta de entre los candidatos propuestos por los grupos parlamentarios y resultarán elegidos quienes por orden correlativo obtengan la mayoría de votos. Así pues, ni el art. 3.2 RPA se refiere al art. $36 \mathrm{RPA}^{41}$ cuando determina el procedimiento a seguir para la elección de la Mesa del Parlamento, ni este último precepto se menciona en ningún momento en el título preliminar del RPA, dedicado a la sesión constitutiva del Parlamento. El núcleo de las demanda de amparo se refiere a la interpretación de lo dispuesto en el art. 36 RPA, que, si bien el TC admite que puede suscitar dificultades interpretativas, lo que resulta innegable es que, sea cual fuere el alcance que deba darse a lo dispuesto en dicho precepto, el RPA es taxativo cuando determina el modo en que el Pleno debe proceder en la sesión constitutiva a la elección de los miembros de la Mesa, esto es, «de acuerdo con el procedimiento regulado en los arts. 33 y 34 de este Reglamento» (art. 3.2 RPA). Por tanto, considera que la aplicación en el caso del art. $36 \mathrm{RPA}$, en la interpretación que de este llevó a cabo el presidente de la sesión constitutiva del Parlamento de Andalucía, privó injustificadamente a la diputada recurrente de su derecho a formar parte como secretaria de la Mesa del Parlamento de Andalucía.

La Sala Segunda, en las sentencias 224/2016 y 225/2016, de 19 de diciembre, resolvió dos recursos de amparo similares planteados por distintos diputados del Parlamento de Cataluña frente a unos mismos Acuerdos de la

40 Conforme a los resultados de la votación celebrada el 16 de abril de 2015, debió pues ser proclamada secretaria primera (como lo fue) la candidata del PSOE, que obtuvo 47 votos; secretaria segunda a la recurrente, con 33 votos; y secretario tercero el candidato de Ciudadanos (C's), con nueve votos (finalmente proclamado como secretario segundo). Sin embargo, el presidente de la sesión constitutiva del Parlamento decidió unilateralmente excluir a la diputada recurrente y nombrar como secretario de la Mesa (secretario tercero) al diputado propuesto por Izquierda Unida (IU), que solo obtuvo cinco votos.

41 Dicho precepto dispone: «Todos los partidos, federaciones y coaliciones que, habiendo concurrido a las anteriores elecciones, hubieran obtenido en las mismas representación suficiente para constituir grupo parlamentario, tendrán derecho a estar presentes en la Mesa». 
Mesa del citado Parlamento. La cuestión suscitada se centraba en determinar si los Acuerdos de la Mesa del Parlamento de Cataluña mediante los que se había admitido a trámite la solicitud de dos grupos parlamentarios de creación de tres ponencias parlamentarias conjuntas de acuerdo con el procedimiento que prevé el art. 126 RPC, para la elaboración, respectivamente, de una Proposición de Ley Integral de Protección Social Catalana, de una Proposición de Ley del Régimen Jurídico Catalán y de una Proposición de Ley de la Administración Tributaria Catalana, vulneraron el derecho de los diputados recurrentes a acceder en condiciones de igualdad a las funciones y cargos público regulado en el art. 23.2 CE, en relación con el derecho de los ciudadanos a participar en los asuntos públicos a través de sus representantes, previsto en el art. 23.1 CE. Los diputados recurrentes, en ambos recursos, consideraban que, de acuerdo con lo previsto en el art. $126 \mathrm{RPC}$, no es posible utilizar el cauce que proporciona dicho precepto - consistente en constituir una ponencia con representación de todos los grupos parlamentarios-, cuando la finalidad de la misma es elaborar el texto de varias proposiciones de ley cuyo contenido no se refiere a materias directamente relacionadas con el desarrollo básico del EAC. Analiza el TC el RPC y su art. 126, y llega a la conclusión de que dicho precepto contempla una especialidad dentro del procedimiento legislativo, relativa a la iniciativa para promover la elaboración conjunta de proposiciones de ley de desarrollo básico del EAC, que regula la posibilidad de que la iniciativa parlamentaria se ejerza por el conjunto de grupos parlamentarios, mediante la constitución de una ponencia redactora que contara con la presencia de todos los grupos; para llevar a cabo tal procedimiento es requisito sine qua non que la iniciativa se dirija a elaborar proposiciones de ley relativas «al desarrollo básico de lo establecido por el Estatuto de Autonomía de Cataluña», lo que remite al art. 62.2 EAC, con arreglo al cual son leyes de desarrollo básico del Estatuto «las que regulen directamente las materias mencionadas en los arts. 2.3, 6, 37.2, 56.2, 67.5, 68.3, 77.3, 79.3, 81.2 y 94.1 EAC», lista de preceptos que configura claramente un numerus clausus. Destaca el TC que no cabe apreciar la necesaria correspondencia «directa» entre las materias de desarrollo básico del Estatuto señaladas y las materias respecto de las que se pretende elaborar tres proposiciones de ley utilizando el procedimiento especial previsto en el art. 126 RPC. Por tanto, considera el TC que, en los acuerdos impugnados, la Mesa del Parlamento de Cataluña llevó a cabo una interpretación y aplicación del art. 126 RPC que se separa de los términos literales de este y de su finalidad. Concluye que dichos acuerdos vulneraron el derecho fundamental invocado por los recurrentes, pues se trata de actos de la Mesa relativos a la tramitación de tres iniciativas legislativas conjuntas que imponen a los recurrentes su participación en una 
ponencia en la que no quieren integrarse, viendo afectada su libertad de iniciativa legislativa, al verse forzados en contra de lo expresamente previsto en el EAC y en el RPC, a formar parte de un procedimiento legislativo especial que no promueven, que los obliga a participar en tres ponencias redactoras cuyo objeto no comparten porque no corresponden al cauce legalmente previsto, y cuya actividad parlamentaria se ve restringida en todas las fases del procedimiento, incluyendo la de su aprobación definitiva, sin que concurran los presupuestos que legitimen dicha restricción.

5. Sobre el art. $24 \mathrm{CE}$, siempre el más prolífico en la jurisprudencia del TC, destaca en este período la STC 148/2016 (Sala Segunda), de 19 de septiembre — dictada a propósito de la denominada "cláusula suelo»— que consideró lesivo del derecho a la tutela judicial efectiva la decisión de archivar el proceso judicial entablado por un particular sobre la cláusula suelo, por el hecho de apreciar la excepción procesal de litispendencia respecto de otro procedimiento abierto contra la misma entidad bancaria, iniciado por un colectivo de afectados por el mismo tipo de clausula. Considera el TC, de inicio, que las normas que regulan en nuestro ordenamiento la llamada acción colectiva de cesación de cláusulas contractuales no permiten sustentar la tesis del desplazamiento o exclusión de la acción individual de nulidad de cláusulas abusivas en beneficio de la referida acción de cesación. Al contrario, de la exposición de motivos de la Ley 7/1998, sobre Condiciones Generales de la Contratación, considera el TC que se desprende la efectividad del derecho a la acción de nulidad individual, frente a las acciones colectivas, al ser distintas y no excluyentes. Por tanto, no existen normas que habiliten al juez para acordar la exclusión o archivo del proceso de nulidad individual por la mera admisión a trámite de una acción colectiva de cesación de la misma cláusula. Analiza, a continuación, el TC el tratamiento que recibe la acción de cesación en el ámbito del derecho comunitario, en especial, la Sentencia del TJUE de 14 de abril de $2016^{42}$. Se trataba del ejercicio de acciones individuales de nulidad de cláusula suelo incorporada en contratos de préstamo, que se impugnan por abusivas, y en los que la entidad financiera demandada solicitó la suspensión de los procedimientos por estar admitida a trámite una demanda de cesación interpuesta por la asociación ADICAE ante otro juzgado, entre las que figuraban cláusulas con el mismo contenido que aquéllas. El juzgado promotor de las

42 Relativa a las cuestiones prejudiciales suscitadas en relación con el art. 7 de la Directiva 93/13/CEE, planteadas por el Juzgado de lo Mercantil núm. 9 de Barcelona, en torno justamente al problema analizado, bien que desde la óptica de la infracción del ordenamiento comunitario. 
cuestiones prejudiciales accedió a la suspensión solicitada aplicando el art. 43 de la Ley de Enjuiciamiento Civil (LEC), esto es, apreciando prejudicialidad —que no litispendencia - y elevó al TJUE la consulta de si la interpretación que sostiene de aquel precepto, con la consecuencia de suspender el procedimiento individual hasta que recaiga Sentencia firme en el proceso de cesación colectivo, puede considerarse o no un "medio eficaz» de tutela de los derechos de los consumidores, en orden a lo previsto en el art. 7 de la Directiva 93/13/ $\mathrm{CEE}^{43}$. El criterio del TJUE resultó contrario a considerar respetuosa la interpretación que se analiza en el presente caso con el art. 7 de la Directiva indicada. Se fundó, para ello, en las diferencias que existen entre las acciones de cesación y las acciones individuales, pues siendo las primeras de "carácter preventivo y [...] finalidad disuasoria», ambas «tienen, en el marco de la Directiva 93/13, objetos y efectos jurídicos diferentes [...] sin que la articulación de esas diferentes acciones deba conducir a una merma de la protección de los consumidores, tal como está prevista en la Directiva 93/13». Y recuerda que, si bien «corresponde al ordenamiento jurídico interno de cada Estado miembro establecer» las reglas que regulen las relaciones entre ambas clases de acciones, dichas reglas deben cumplir tanto con el principio de equivalencia («no sean menos favorables que las que rigen situaciones similares sometidas al Derecho interno»), como el de efectividad («que no hagan imposible en la práctica o excesivamente difícil el ejercicio de los derechos que el derecho de la Unión confiere a los consumidores»). Es este segundo principio el que se considera inobservado por el TJUE, pues la solución propuesta «puede redundar en perjuicio de la efectividad de la protección prevista por esta Directiva a la luz de las diferencias en cuanto al objeto y la naturaleza de los mecanismos de protección de los consumidores que se materializan en esas acciones», dado que "el consumidor queda obligatoriamente vinculado por el resultado de la acción colectiva, incluso cuando decida no participar en la misma, y la obligación que

43 Recuerda el TC que el TJUE no se pronuncia sobre la eventual contradicción del art. 43 de la LEC con el derecho comunitario, sino acerca de la interpretación judicial del mismo ofrecida por el órgano judicial que suscita la cuestión: «[...] tal como se desprende de la interpretación del órgano judicial remitente, en circunstancias como las que concurren en este caso, ese órgano jurisdiccional está obligado, en virtud del art. 43 de la Ley de enjuiciamiento civil, a suspender la acción individual de la que conoce hasta que se resuelva mediante sentencia firme la acción colectiva cuya solución pueda aplicarse respecto de la acción individual y, de ese modo, el consumidor no puede hacer valer de forma individual los derechos reconocidos por la Directiva 93/13 desvinculándose de dicha acción colectiva» (STJUE, apartado 35; en términos similares también el apartado 38). 
el art. 43 LEC impone al juez nacional, impide a este realizar un análisis propio de las circunstancias que concurren en el asunto del que conoce». Como consecuencia de lo expuesto, colige el TJUE que tal regla nacional no constituye un medio adecuado ni eficaz para que cese el uso de cláusulas abusivas ${ }^{44}$. Considera el TC que la lectura de los Autos impugnados evidencia que, prescindiendo del marco normativo propio de las acciones colectivas de cesación al que debía atenderse, tanto el Juzgado, que en esto declara seguir el criterio que entonces conocía de la propia sección ad quem, como sobre todo esta última, han denegado la tutela jurisdiccional solicitada a través de la demanda de nulidad individual de cláusula abusiva, remitiendo a los actores a un proceso de cesación iniciado casi dos años antes en un Juzgado de Madrid por una asociación de consumidores. En consecuencia, considera que extender de manera automática un efecto de cosa juzgada derivado de la estimación de la acción de cesación a todas las cláusulas iguales insertas en la universalidad de contratos en vigor, además de no preverse en las normas que regulan dicha acción colectiva, puede llegar a atentar contra la autonomía de la voluntad del consumidor. En definitiva, se estima la demanda por vulneración del derecho de acceso a la jurisdicción de los recurrentes, por carecer de base legal las resoluciones recurridas.

También con el derecho de acceso a la justicia en juego, en la STC 163/2016 (Sala Segunda), de 3 de octubre, se impugnaba una resolución judicial que inadmitió el recurso contencioso-administrativo interpuesto, por incumplimiento de la exigencia del art. 45.2 d) de la Ley Reguladora de la Jurisdicción Contencioso-Administrativa (LJCA), sobre la aportación de los documentos que acrediten el cumplimiento de los requisitos exigidos para entablar acciones las personas jurídicas con arreglo a las normas o estatutos que les sean de aplicación. Tras citar la doctrina sobre el derecho de acceso a la justicia, recuerda el TC que, sobre la subsanabilidad de los trámites

44 Como resultado, declara en su parte dispositiva que «el art. 7 de la Directiva 93/13/ CEE del Consejo, de 5 de abril de 1993, sobre las cláusulas abusivas en los contratos celebrados con consumidores, debe interpretarse en el sentido de que se opone a una normativa nacional, como la de los litigios principales, que obliga al juez que conoce de una acción individual de un consumidor, dirigida a que se declare el carácter abusivo de una cláusula de un contrato que le une a un profesional, a suspender automáticamente la tramitación de esa acción en espera de que exista Sentencia firme en relación con una acción colectiva que se encuentra pendiente, ejercitada por una asociación de consumidores de conformidad con el apartado segundo del citado artículo con el fin de que cese el uso, en contratos del mismo tipo, de cláusulas análogas a aquella contra la que se dirige dicha acción individual». 
procesales, ha afirmado que se debe conceder la posibilidad de subsanación incluso en el caso de que no existiera una previsión legal expresa, cuando, atendida la ratio de su exigencia procesal, sea susceptible de reparación sin menoscabo de la regularidad del procedimiento y sin daño de la posición de la parte adversa. En el caso analizado, la actora al interponer el recurso contencioso-administrativo acompañó, entre otros documentos, un certificado expedido por el administrador único de la entidad recurrente, en el que se hacía constar que por el órgano de administración de la misma se había autorizado la interposición de recurso contencioso-administrativo contra el referido acto administrativo. Dicha demanda dio lugar al procedimiento abreviado, en el cual, por diligencia de ordenación se requirió la subsanación de dos defectos de la demanda, sin que en dicha resolución se hiciera mención alguna al certificado aportado al efecto de acreditar el cumplimiento del requisito del art. 45.2 d) LJCA. Sin embargo, en la celebración de la correspondiente vista, la Administración demandada opuso, al contestar la demanda en dicho acto, causa de inadmisibilidad del recurso contencioso-administrativo por no ser suficiente el certificado aportado a los efectos previstos en el citado precepto, sin que el órgano judicial diera traslado a la actora para alegaciones sobre la causa de inadmisibilidad opuesta, y sin que se pronunciara sobre la continuación o no de la vista. Celebrada esta, se dictó posteriormente Sentencia inadmitiendo el recurso contencioso-administrativo, al apreciar el juzgador la causa de inadmisibilidad opuesta por la Administración demandada en la contestación a la demanda, argumentando que la recurrente nada había opuesto a la causa de inadmisibilidad, no constando en autos qué órgano social había autorizado el ejercicio de acciones ni si tenía facultades para ello. Ante estas circunstancias, afirma el TC que, si bien el art. 45.2 LJCA exige aportar con el escrito de interposición del recurso contencioso-administrativo, entre otros documentos, los que acrediten el cumplimiento de los requisitos exigidos a las personas jurídicas para entablar acciones con arreglo a las normas o estatutos que les sean de aplicación, no cabe obviar que la omisión de dicho requisito resulta subsanable, como se deduce del apartado 3 del mismo art. 45 LJCA. En el presente caso el presunto defecto se ha producido en un procedimiento abreviado que presenta una regulación y un desarrollo singulares, establecidos en el art. $78 \mathrm{LJCA}^{45}$. En virtud de tal precepto, alegada que

45 Art. 78 de la LJCA: «6. La vista comenzará con exposición por el demandante de los fundamentos de lo que pida o ratificación de los expuestos en la demanda. 7. Acto seguido, el demandado podrá formular las alegaciones que a su derecho convengan, comenzando, en su caso, por las cuestiones relativas a la jurisdicción, a la competencia objetiva y territorial y a cualquier otro hecho o circunstancia que pueda obstar a 
fue por la demandada la causa de inadmisibilidad referida al incumplimiento del requisito del art. 45.2 d) LJCA, el órgano judicial venía obligado, en primer lugar, a oír al demandante sobre dicha cuestión obstativa a la admisión del recurso contencioso-administrativo, y, en segundo lugar, a resolver en el acto sobre su concurrencia o no, pronunciándose sobre si la vista debía continuar o no. Sin embargo, no lo hizo así, sino que incumplió ambos mandatos, continuando la celebración de la vista sin la referida audiencia y sin adoptar decisión alguna en el acto, para posteriormente apreciar la concurrencia del óbice procesal en el momento de dictar la sentencia impugnada, con el resultado de inadmitir el recurso contencioso-administrativo por la concurrencia de la causa opuesta por la Administración demandada. Concluye el TC afirmando que la constatación de tal vulneración del derecho a la tutela judicial efectiva debe conllevar la estimación del recurso de amparo.

6. Sobre las garantías procesales establecidas en el art. 24.2 CE, en la STC 172/2016 (Sala Primera), de 17 de octubre, el objeto se refería a la actuación del demandante —en su día juez de Primera Instancia— que prolongó durante dos días el período de estancia de vacaciones de un menor con su padre con el fin de que el niño pudiera salir en la madrugada del Viernes Santo como paje de una cofradía. La decisión fue adoptada sin dar audiencia a la madre, al aceptar el juez la medida cautelar solicitada por el abuelo del menor y tras expresar el niño su deseo de participar en la procesión. Como consecuencia de la querella presentada por la madre del niño, el juez demandante de amparo fue condenado a dos años de inhabilitación como autor de un delito de prevaricación culposa, al considerarse que había obviado las medidas familiares fijadas por un Juzgado de Violencia. El Tribunal Supremo apreció intencionalidad en los hechos, lo consideró autor de un delito de prevaricación dolosa y elevó la pena a diez años de inhabilitación especial para el cargo de juez. El recurrente argumentaba que la Sentencia dictada por el Tribunal Supremo había vulnerado sus derechos por haber reconstruido la argumentación de un recurso planteado erróneamente por la acusación. A este respecto, el TC afirma que «el argumento utilizado por el Supremo de considerar preponderante la voluntad impugnativa del recurrente, frente a la

la válida prosecución y término del proceso mediante sentencia sobre el fondo. 8 . Oído el demandante sobre estas cuestiones, el Juez resolverá lo que proceda, y si mandase proseguir el juicio, el demandado podrá pedir que conste en acta su disconformidad. Lo mismo podrá hacer el demandante si el Juez, al resolver sobre alguna de dichas cuestiones, declinara el conocimiento del asunto en favor de otro Juzgado o Tribunal o entendiese que debe declarar la inadmisibilidad del recurso». 
defectuosa formalización del motivo - la cual, como tal, no se niega - no se compadece con el carácter extraordinario del recurso de casación, tasado y estricto en sus presupuestos». Ese carácter tasado "generaba la confianza legítima» en el demandante de amparo de que el motivo del recurso «no resultaría estimado en sentencia por no haberse planteado adecuadamente». El TC no cuestiona la argumentación contenida en la Sentencia dictada por el Tribunal Supremo, pero considera que este incurrió en un «exceso de jurisdicción (el motivo no debió ser admitido, tal como se planteaba, y menos todavía estimarlo), en cuanto al respeto a los presupuestos legales del recurso de casación», lo que ha causado la lesión del derecho al recurso del demandante (art. 4.1 CE). También considera el TC que la Sentencia dictada en casación vulnera el derecho a un proceso con todas las garantías y a no sufrir indefensión (art. 24.2 CE), ya que la condena por prevaricación dolosa (delito del que el recurrente había sido absuelto en primera instancia) «se produce sobre la base de la revalorización probatoria de la conducta del recurrente». Explica la Sentencia que, según la doctrina constitucional y la del Tribunal Europeo de Derechos Humanos (TEDH):

[...] vulnera el derecho a un proceso con todas las garantías que un órgano judicial, conociendo en vía de recurso, condene a quien había sido absuelto en la instancia o empeore su situación a partir de una nueva valoración de pruebas personales o de una reconsideración de los hechos estimados probados para establecer su culpabilidad, siempre que no se haya celebrado una audiencia pública en que se desarrolle la necesaria actividad probatoria [...]

En este caso, la agravación de la condena se fundó «exclusivamente, en una distinta valoración de pruebas personales (declaración del acusado y testificales)", sin que la presencia del acusado en estrados durante la celebración de la vista del recurso de casación pueda considerarse garantía suficiente. La vista de los recursos de casación, señala la Sentencia, «no permite articular la celebración práctica de pruebas, tal y como la propia Sala de lo Penal del Tribunal Supremo, máximo intérprete de la legalidad procesal», ha reconocido en un acuerdo de 19 de diciembre de 2012. La Sentencia cuenta con dos opiniones discrepantes ${ }^{46}$.

46 Carlos Ortega Carballo. 